\title{
IDEOLOGISASI IDENTITAS ASWAJA AN-NAHDLIYAH DI LP. MA'ARIF NU LUMAJANG DALAM MENANGKAL GERAKAN ISLAM TRANSNASIONAL
}

\author{
Zainil Ghulam \\ Institut Agama Islam Syarifuddin Lumajang, Indonesia \\ Email: wanlam99@gmail.com \\ Achmad Farid \\ Institut Agama Islam Syarifuddin Lumajang, Indonesia \\ Email: ac.faried@gmail.com
}

\begin{abstract}
Abstrak: Artikel ini mengulas tentang upaya yang dilakukan oleh Lembaga Pendidikan Ma'arif Nahdaltul Ulama (NU) Lumajang dalam membumikan identitas Aswaja An-Nahdliyah. Secara khusus, penanaman identitas Aswaja AnNahdliyah dilakukan untuk menangkal gerakan Islam Transnasional yang sedang marak terjadi di Lumajang terutama di lingkungan lembaga pendidikan Ma'arif Nahdlatul Ulama. Penelitian ini menggunakan penelitian lapangan (field research) dengan metode kualitatif. Penelitian dilakukan di lembaga pendidikan Ma'arif di beberapa daerah di Lumajang. Kesimpulan penelitian ini menyebutkan bahwa proses yang dilakukan oleh LP Ma'arif dan seluruh lembaga pendidikan di lokasi penelitian memiliki iklim dan kebudayaan Nahdlatul Ulama itu sendiri. Selain itu, amaliyah dan tradisi kegamaan Nahdlatul Ulama dijadikan sebagai kegiatan rutinan. Antara lain tahlil, istighotsah, ziarah kubur dengan melibatkan stakeholder lain baik dari unsur wali murid maupun masyarakat pada umumnya. Selain kegiatan rutin, literasi tentang ke-NU-an juga dilakukan dengan menjadikan majalah AULA PWNU Jawa Timur sebagai pedoman penerimaan berita dan informasi terkini tentang NU.
\end{abstract}

Kata kunci: ideologisasi, aswaja an-Nahdliyah, Transnasional

\section{Pendahuluan}

Perlahan tapi pasti, perubahan nalar moderasi Islam di Indonesia ditengarai dalam ancaman. Karena gerakan Islam transnasional membawa paham baru yang berbeda dengan akar dan budaya bangsa Indonesia yang telah lama terbangun. Hasil survey survei Lembaga Studi Center of Strategic and International Studies (CSIS) pada tahun 2012 tentang toleransi agama di Indoonesia, menunjukkan bahwa toleransi beragama orang Indonesia tergolong rendah, kalaupun masyarakat beragama siap hidup berdampingan dalam kehidupan sosial, namun ketika terkait dengan pembangunan tempat ibadah, ada kecenderungan kelompok mayoritas tidak menyetujui. Dari 2.213 responden di 23 propinsi Indonesia, 59,5\% responden tidak keberatan bertetangga dengan orang yang beda agama, sedangkan 33,7 \% memilih menolak tetangga yang beda agama. Kemudian terkait dengan pembangunan tempat ibadah, 68,2\% responden memilih menolak pembangunan tempat ibadah dari agama lain, hanya 22,1\% lainnya mengaku tidak keberatan. ${ }^{1}$

Keadaan ini banyak mendapat respon beragam, terutama oleh Nahdlatul Ulama yang ada dan lahir jauh sebelum Indonesia merdeka. Bagi NU, Islam sebagai agama dan negara-bangsa ibarat jiwa dan raga, keduanya membentuk satu entitas yaitu Islam Indonesia. ${ }^{2}$ Terutama Nahdlatul Ulama (NU), ia memiliki karakteristik yang berbeda yang mampu menggambarkan adaptasi mereka dengan negara. Karakteristik itu adalah Aswaja yang di dalamnya mempunyai

1 http://www.thejakartapost.com/news/2012/06/06/ri-becomes-more-intoleransi-html, (14 Juni 2018)

${ }^{2}$ Kerjasama harian kompas dengan Pengurus pusat lembaga kajian dan pengembangan sumberdaya Manusia (PP Lakpesdam) NU, Nasional-isme dan Islam NU-Santara (Jakarta: PT. Kompas Media Nusantara, 2017), 67-68. Dalam penjelasan lainnya, Islam sebagai ajaran kerohanian yang bersifat universal, sementara entitas kebangsaan adalah realitas kehidupan yang bersifat lokal. Yang universal sebagai esensi, selalu membutuhkan yang lokal sebagai media aktualisasi. 
nilai ideologi Islam moderat. ${ }^{3}$ Bahkan dalam muktamar ke-33 Nahdlatul Ulama yang dihelat di Jombang, Jawa Timur, 1-5 Agustus 2015 NU kembali menegaskan posisi Aswaja. ${ }^{4}$ Dalam muktamar tersebut, terdapat hasil tentang khashaish Ahlus Sunnah Wal Jama'ah Al-Nahdliyah yakni berupa karakter Aswaja An-Nahdliyah di tubuh NU itu sendiri. ${ }^{5}$

Belakangan, 'keresahan' akan diaspora gerakan transnasional juga dirasakan di Lumajang. Setidaknya pernah kasus penyebaran selebaran gelap berfaham Wahabi pernah dijumpai, ${ }^{6}$ selebaran itu diedarkan ke rumah warga secara sembunyi-sembunyi, bahkan ditempelkan di pohon-pohon. Selebaran itu berisi larangan untuk membaca "Bismillah", Qunut serta Tahlil dan juga ada buletin radikal yang tersebar di beberapa masjid dan kalangan pelajar. Dalam buletin tersebut berisi pemahaman ayat Al-Qur'an yang dikupas tanpa ada upaya membumikannya dalam konteks kehidupan sosial. ${ }^{7}$ Dalam kasus lain, pernah ada simpatisan ISIS dari Lumajang bernama Tiara, dia berangkat ke Suriah bersama saudara iparnya yaitu Ririn. ${ }^{8}$ Dan juga kasus penemuan anggota PNS Lumajang yang diketahui sebagai anggota HTI. ${ }^{9}$ Yang lebih parah, sekolah TK milik warga di daerah Gedok Senduro, belakang sudah berubah menjadi TK golongan tertentu. ${ }^{10}$ Berdasarkan preliminary research penulis yang bersifat observatif, nampaknya kegelisahan akan munculnya gerakan ini ditangkap oleh PCNU Lumajang melalui berbagai upaya, termasuk memperkuat fondasi ideologi dilingkungan NU, terutama di lembaga-lembaga pendidikan. ${ }^{11} \mathrm{LP}$ Ma'arif sendiri, yang menjadi ujung tomak problem ini, memiliki agenda melakukan pemantapan Aswaja secara massif di lembaga-lembaga pendidikan di bawahnya. Oleh karena itu, penelitian ini menjadi sangat strategis untuk melihat bagaimana pola ideologisasi yang dilakukan oleh LP Ma'arif terhadap lembaga pendidikan di bawahnya.

${ }^{3}$ Harian kompas dan PP Lakpesdam NU, Nasional-isme dan, 71-72 dalam pembicaraan M. Imdadun Rahmat dalam acara silaturrahim anak bangsa yang diselenggarakan Forum generasi muda Nahdlatul Ulama (FGMNU) cabang Sumenep (18/10/2008). Sayap kanan NU adalah Keislaman dan sayap kirinya adalah Pancasila.

${ }^{4}$ Harian kompas dan PP Lakpesdam NU, nasional-isme dan, 59

5Pengurus besar Nahdlatul Ulama, hasil-hasil muktamar ke-33 Nabdlatul Ulama, (Jakarta: Lembaga Ta'lif wan Nasyr PBNU, 2016), 172

"selebaran gelap tentang PKS berfaham Wahabi beredar di Lumajang" dalam https://nasional.tempo.co/read/229078/selebaran-gelap-tentang-pks-berpaham-wahabi-beredar-di-lumajang

(diakses pada 28 April 2018) wilayah penyebaran ini meliputi kecamatan Klakah, Ranuyoso, Kedungjajang, dan Randuagung.

7“buletin radikal beredar di Lumajang” dalam http://www.nu.or.id/post/read/27947/buletin-radikal-beredar-dilumajang (diakses pada 28 April 2018)

${ }^{8 " W a n i t a ~ i n i ~ b e b e r k a n ~ p e r k e n a l a n ~ d e n g a n ~ W N I ~ s i m p a t i s a n ~ I S I S ~ d i ~ T u r k i " ~ d a l a m ~}$ https://www.merdeka.com/peristiwa/wanita-ini-beberkan-perkenalan-dengan-wni-simpatisan-isis-di-turki.html

(diakses pada 28 April 2018) dalam penjelasan lain, Direktur Pencegahan Badan Nasional Penanggulangan Terorisme (BNPT), Brigjen Hamli mengatakan, bahwa ISIS sudah masuk di 16 daerah di Jawa Timur termasuk Lumajang. Dalam https://www.jawapos.com/read/2017/06/12/137132/waspadalah-isis-sudah-masuk-di-16-daerah-jawatimur (diakses pada 28 April 2018)

"'ada empat PNS di Lumajang diketahui sebagai anggota HTI" dalam http://m.jatimtimes.com/baca/156016/20170727/163334/ada-4-pns-di-lumajang-diketahui-sebagai-anggota-hti/

(diakses pada 28 April 2018) pernyataan kepala badan Kesbangpol Lumajang Ir. Suyanto (27/07/2017) bahwa ke empat anggota tersebut masih aktif jadi PNS dan salahsatu dari mereka jadi pengurus aktif dalam organisasi HTI di Lumajang.

${ }^{10}$ Pernyataan Sekretaris PCNU Lumajang dalam sambutan kegiatan Lakpesdam NU Lumajang, Media dan Upaya Melawan Propaganda, 12 Juni 2018. Bandingkan dengan pernyataan Ahmad Gaus AF. Ia melakukan penelitian tentang cara-cara menggandeng, mengkampenyekan ideologi radikal, dan mengajarkan secara sistematis dengan menopang pada kurikulum PAI yang diajarkan di sekolah, merupakan salah satu strategi yang dikembangkan dan dijalankan oleh kelompok-kelompok tersebut. Hal ini ditunjukkan dengan keberadaan guru-guru agama yang ada di empat daerah penelitiannya, kebanyakan bergabung dengan komunitas organisasi tersebut. Oleh karena itulah, demi sebuh cita-cita menjaga kedaulatan dia merekomendasikan kepada Kepala Sekolah agar lebih selektif dalam memilih guru Pendidikan Agama Islam di wilayahnya. Lihat Akhmad Gaus AF, "Pemetaan Problem Radikalisme di SMU Negeri di 4 Daerah”, dalam Jurnal Ma’arif Institute, Vol. 8, No 1, Juli 2013, 174

11 Pernyataan ketua PCNU Lumajang (KH. Nur Sjahid) dalam sambutannya di acara pelantikan PMII Komisariat Syarifuddin di gedung NU Lumajang pada tanggal 07 April 2018 


\section{Pengertian dan Historiografi Aswaja al-Nahdliyah}

Dinamika pemikiran dan sejarah peradaban Islam tidak pernah statis. Dari zaman ke zaman percaturan corak pemahaman terus berkembang menyesuaikan diri dengan kebutuhan masyarakat, termasuk di dalamnya bagaimana pemahaman teologis. Dalam konteks sejarah, pasca wafatnya Nabi Muhammad SAW, perbedaan pandangan tentang Islam yang benar muncul sangat beragam. Ada yang berasal dari kerangka berfikir dan corak politis. Ada pula yang beragumentasi pemahaman tersebut berakar dari pemahaman yang paling benar. Ada pula yang menyengaja keluar dari pemahaman umum, untuk membentuk pemahaman baru karena tidak sepaham.

Term Aswaja merupakan postulat dari ungkapan Rasulullah SAW., "Ma> ana 'alaibi wa asha $>b i " .{ }^{12}$ Berarti, golongan aswaja adalah golongan yang mengikuti ajaran Islam sebagaimana diajarkan dan diamalkan Rasulullah beserta sahabatnya. Aswaja (Ahlussunah wa al-jama'ah) adalah satu di antara banyak aliran dan sekte yang bermuculan dalam tubuh Islam. Di antara semua aliran, kiranya aswajalah yang punya banyak pengikut, bahkan paling banyak di antara semua sekte. Hingga dapat dikatakan, Aswaja memegang peran sentral dalam perkembangan pemikiran keIslaman.

Aswaja tidak muncul dari ruang hampa. Ada banyak hal yang mempengaruhi proses kelahirannya dari rahim sejarah. Di antaranya yang cukup populer adalah tingginya suhu konstelasi politik yang terjadi pada masa pasca Nabi wafat . Kematian Utsman bin Affan, khalifah ke-3, menyulut berbagai reaksi. Utamanya, karena ia terbunuh, tidak dalam peperangan. Hal ini memantik semangat banyak kalangan untuk menuntut Imam Ali, pengganti Utsman untuk bertanggung jawab. Terlebih, sang pembunuh, yang ternyata masih berhubungan darah dengan Ali, tidak segera mendapat hukuman setimpal.

Muawiyah bin Abu Sofyan, Aisyah, dan Abdulah bin Thalhah, serta Amr bin Ash adalah beberapa di antara sekian banyak sahabat yang getol menuntut Ali. Bahkan, semuanya harus menghadapi Ali dalam sejumlah peperangan yang kesemuanya dimenangkan pihak Ali. ${ }^{13}$ Dan yang paling mengejutkan, adalah strategi Amr bin Ash dalam perang Shiffin di tepi sungai Eufrat, akhir tahun $39 \mathrm{H}$, dengan mengangkat mushaf di atas tombak. Tindakan ini dilakukan setelah pasukan Amr dan Muawiyah terdesak. Tujuannya, hendak mengembalikan segala perselisihan kepada hukum Allah. Dan Ali setuju, meski banyak pengikutnya yang tidak puas.

Akhirnya, tabkim (arbritase) di Daumatul Jandal, sebuah desa di tepi Laut Merah beberapa puluh km utara Makkah, menjadi akar perpecahan pendukung Ali menjadi Khawarij dan Syi'ah. Kian lengkaplah perseteruan yang terjadi antara kelompok Ali, kelompok Khawarij, kelompok Muawiyah, dan sisa-sisa pengikut Aisyah dan Abdullah ibn Thalhah. ${ }^{14}$ Ternyata, perseteruan politik ini membawa efek yang cukup besar dalam ajaran Islam. Hal ini terjadi tatkala banyak kalangan menunggangi teks-teks untuk kepentingan politis. Celakanya, kepentingan ini begitu jelas terbaca oleh publik, terlebih masa Yazid bin Muawiyah.

Pemakaian Ahlus sunnah wal jama'ah sebagai sebutan bagi kelompok keagamaan justru diketahui lebih belakangan, sewaktu Az-Zabidi menyebutkan dalam Itha $>f S_{a}>$ datul Muttaqi $>n$, jika disebutkan ahlussunnah, maka yang dimaksud adalah pengikut Al-Asy'ari dan Al-Maturidi. Dari aliran ahlussunnah waljamaah atau disebut aliran sunni dibidang teologi kemudian juga berkembang dalam bidang lain yang menjadi ciri khas aliran ini, baik dibidang fiqh dan tasawuf. sehingga menjadi istilah, jika disebut akidah sunni (ahlussunnah waljamaah) yang dimaksud adalah pengikut Asy'aryah dan Maturidyah. Atau Fiqh Sunni, yaitu pengikut madzhab yang empat ( Hanafi, Maliki, Syafi ${ }^{e e}$ dan Hanbali). Yang menggunakan rujukan alqur'an, al-hadits, ijma' dan qiyas. Atau juga Tasawuf Sunni, yang dimaksud adalah pengikut metode tasawuf Abu Qashim Abdul Karim al-Qusyairi, Imam Al-Hawi, Imam Al-Ghazali dan Imam Junaid al-Baghdadi. Yang memadukan antara syari'at, hakikat dan makrifat. ${ }^{15}$

\footnotetext{
12 Said Aqil Siradj, "Kontroversi Aswaja: Aula Perdebatan dan Reinterpretasi” (Yogyakarta: LKiS, 2004)182.

${ }^{13}$ Harun Nasution, Teologi Islam; Aliran-Aliran, Sejarah Analisa Perbandingan, (Jakarta: UI Pres, 2008), 65.

${ }^{14}$ Ibid, 78

$$
15 \text { Ibid. }
$$
}


a. Aqidah

Dimensi tauhid atau yang lebih dikenal dengan sebutan aqidah Ahlussunnah wal Jama'ah terbagi atas beberapa bagian yang terkandung dalam arka $>n$ al-i>ma $>n$ (rukun-rukun). Terminologi iman adalah membenarkan dengan hati, mengucapkan dengan lisan dan mengamalkan melalui anggota badan. Rukun iman dalam pahama aqidah abl al-sunnab wa aljama >'ah dapat diimplementasikan dalam wujud iman kepada Allah, malaikat, kitab (alQur'an), rasul, hari akhir (kiamat), qada' dan qadar. ${ }^{16}$

1) Keimanan kepada Allah berarti percaya dengan seutuhnya kepadaNya. Dengan mempercayai 20 sifat yang menjadi sifat dalam dzat-Nya, yaitu: Wuju>d (Maha Ada), Qidam (Dahulu), Baqa>' (Kekal), Mukhalafah li al-bawa>disti (Berbeda dengan yang lain), Qiya $>$ mubu bi nafsibi> (Berdiri sendiri), Wabda $>$ niyah (Satu), Qudrat (Kuasa), Ira $>$ dah (Berkehendak), 'Tlmu (Mengetahui), Hayah (Hidup), Sama>' (Mendengar), Bashar (Melihat), Kala $>m$ (Berbicara), Qa $>$ diran (Maha Kuasa), Muri $>$ dan (Maha Menentukan), 'A>liman (Maha Mengetahui), Hayyan (Maha Hidup), Sami'an (Maha Mendengar), Bashi>ran (Maha Melihat) dan Mutakalliman (Maha Berfirman) ${ }^{17}$

2) Keimanan kepada malaikat berarti percaya terhadap adanya suatu makhluk halus yang diciptakan oleh Allah SWT dari cahaya, mereka tercipta sangat taat kepada Allah, jumlahnya pun sangat banyak akan tetapi menurut Ahlussunnah wal Jama'ah malaikat yang wajib diketahui jumlahnya hanya 10, yaitu: malaikat Jibril, Mikail, Israfil, 'Izrail, Mungkar, Nakir, Raqib, Atid, Malik, dan Ridlwan. Mereka mempunyai tugas masing-masing yang tidak pernah mereka langgar sedikitpun. Sebagai konsekuensi terhadap keyakinan adanya makhluk halus yang bernama malaikat tersebut, umat Islam pun harus mempercayai adanya makhluk halus lain yang bernama jin, setan atau iblis. ${ }^{18}$

3) Keimanan kepada kitab-kitab suci berarti umat Islam aliran Ahlussunnah wal Jama'ah mempercayai adanya kitab yang diturunkan oleh Allah kepada para rasul-Nya untuk kemudian disampaikan kepada umat manusia. Menurut Ahlussunnah wal Jama'ah kitab-kitab yang wajib dipercayai ada empat yakni kitab Taurat yang diturunkan kepada Nabi Musa, kitab Zabur yang diturunkan kepada Nabi Daud, kitab Injil yang diturunkan kepada Nabi Isa dan kitab Al-Qur'an yang diturunkan kepada Nabi Muhammad SAW. ${ }^{19}$

4) Keimanan kepada rasul-rasul Allah adalah keimanan yang harus di miliki oleh umat Islam. Ahlussunnah wal Jama'ah terhadap manusia pilihan Allah (rasul) yang ditugasi untuk membimbing umat manusia kejalan yang benar dan memberikan petunjuk serta menyebarkan ajaran agama Allah. Para Nabi yang wajib diketahui oleh umat Islam Ahlussunnah wal Jama'ah berjumlah $25 \mathrm{Nabi}^{20}$

5) Keimanan kepada hari akhir adalah keimanan yang mengakui adanya batas akhir kehidupan di dunia yang kemudian disebut hari kiamat. Hari kiamat pasti terjadi hanya saja waktunya tidak ada yang tahu selain Allah. Pada hari kiamat ini manusia dan seluruh alam akan mengalami pemusnahan total secara jasad dan raga yang kemudian hanya tinggal rohnya saja dan akan kembali kepada dzat yang menciptakan yakni Allah. ${ }^{21}$

6) Keimanan kepada Qada' dan Qadar adalah keimanan yang harus dimiliki seorang muslim Ahlussunnah wal Jama'ah tentang adanya kepastian dan ketentuan dari Allah. Dengan kata lain segala apa yang terjadi di dunia ini adalah atas kehendak dan ketentuan dari Allah sebagai dzat yang menciptakan, sedangkan manusia menjalani saja. Dengan kata lain bahwa

${ }^{16}$ Muhammad bin Abdul Wahab, “Epistemologi Taubid”. (Yogyakarta: Rajawali Press, 2008), 20.

17 Abdul Aziz, "Konsepsi Ablussunnah Wal Jamaah" (Yogyakarta: Mutiara Ilmua, 2009), 29.

18 Yusuf M. Shadiq, "Aqidah Menurut Empat Madhab”, (Yogyakarta: Teras, 2010), 37.

${ }^{19}$ Ibid, 38

${ }^{20}$ Ibid.

${ }^{21}$ Ibid, 39 
segala sesuatunya Tuhan yang menentukan dan manusia hanya berusaha serta b. Fiqih

mensinergikan dengan ketentuan tersebut. ${ }^{22}$

Dalam bidang syari'ah Ahlussunnah wal Jama'ah menetapkan 4 (empat) sumber yang bisa dijadikan rujukan bagi pemahaman keagamaannya, yaitu al-Qur'an, Sunnah Nabi, Ijma' (kesepakatan Ulama), dan Qiyas, dari keempat sumber yang ada, al-Qur'an yang telah dijadikan sebagai sumber utama. Ini artinya bahwa apabila terdapat masalah kehidupan yang mereka hadapi, terlebih dahulu harus dikembalikan kepada al-Qur'an sebagai pemecahannya.

Apabila masalah tersebut terdapat pemecahannya dalam al-Qur'an, maka selesailah sudah permasalahan tersebut, akan tetapi apabila masalah tersebut tidak ditemukan dalam al-Qur'an, maka hendaklah mencari pemecahannya dalam suunah Nabi SAW. Apabila masalah tersebut ada dalam sunnah Nabi SAW, maka selesailah masalah tersebut. Dan apabila masalah itu tidak ada pemecahannya dalam sunnah Nabi, maka hendaklah mencari di dalam ijma' para abl al-hal wa al-'aqd di kalangan para ulama terdahulu.

Apabila masalah tersebut ada pemecahannya dalam ijma', maka terjawablah permasalahannya tersebut, akan tetapi jika masalah tersebut tidak bisa diselesaikan secara ijma', maka barulah menggunakan akal untuk melakukan ijtihad dengan mengqiyaskan hal-hal yang belum diketahui status hukumnya kepada hal-hal yang sudah diketahui status hukumnya. Adapun pokok ajaran Ahlussunnah wal Jama'ah dalam dimensi syari'ah mencakup dua bagian, yakni tentang 'ubudiyah (yang mengatur tentang hukum Islam) dan mu'a $>$ malah (yang mengatur tentang hubungan manusia dengan benda).

c. Tasawuf

Aspek tasawuf adalah aspek yang berkaitan upaya mendekatkan diri kepada Allah SWT, memantapkan keimanan, mengkhusu'kan ibadah dan memperbaiki akhlak. ${ }^{23}$ Pada dasarnya ajaran tasawuf merupakan bimbingan jiwa agar menjadi suci, selalu tertambat kepada Allah dan terjauhkan dari pengaruh selain Allah. Jadi tujuan tasawuf adalah mencoba sedekat mungkin kepada Allah SWT dengan melalui proses yang ada dalam aturan tasawuf.

Jalan untuk mencapai proses tersebut sangatlah panjang, yang disebut dengan almaqamat. Adapun macam-macam dari al-maqamat itu sendiri yaitu:

1) Maqam taubat, yaitu meninggalkan dan tidak mengulangi lagi suatu perbuatan dosa yang pernah dilakukan, demi menjunjung tinggi ajaranajaran Allah dan menghindari murkanya.

2) Maqam Wara ', yaitu menahan diri untuk tidak melakukan sesuatu guna menjungjung tinggi perintah Allah atau meninggalkan sesuatu yang bersifat subhat.

3) Maqam Zuhud, yaitu lepasnya pandangan kedunian atau usaha memperolehnya dari orang yang sebetulnya mampu memperolehnya.

4) Maqam Sabar, yaitu ketabahan karena dorongan agama dalam menghadapi atau melawan hawa nafsu.

5) Maqam Faqi $>$ r, yaitu perasaan tenang dan tabah di kala miskin harta dan mengutamakan kepentingan orang lain di kala kaya.

6) Maqam Khauf, yaitu rasa ketakutan dalam menghadapi siksa dan azab Allah.

7) Maqam Raja >', yaitu rasa gembira karena mengetahui adanya kemurahan dzat yang Maha Kuasa.

8) Maqam Tawakal, yaitu pasrah dan bergantung kepada Allah dalam kondisi apapun.

9) Maqam Ridha, yaitu sikap tenang dan tabah tatkala menerima musibah sebagaimana di saat menerima nikmat. ${ }^{24}$

Prinsip dasar dari aspek tasawuf adalah adanya keseimbangan kepentingan ukhrawi dan selalu mendekatkan diri kepada Allah, dengan jalan spiritual yang bertujuan untuk memperoleh hakekat dan kesempurnaan hidup manusia. Akan tetapi tidak boleh meninggalkan garis-garis

22 Ibid.

${ }^{23}$ Hamka, Tasawuf Perkembangan dan Pemeriksaannya (Jakarta: Mizan, 1998). 94

${ }^{24}$ Zainuri, Dialektika Tasawuf Lintas Aliran, (Yogyakarta: Teras, 2009), 30. 
syariat yang telah ditetapkan oleh Allah dalam al-Qur'an dan as-Sunnah. Jalan sufi yang telah dicontohkan oleh Nabi Muhammad dan para pewarisnya adalah jalan yang tetap serta teguh memegang perintah-perintah Allah. Karena itu umat Islam tidak dapat menerima jalan sufi yang melepaskan diri dari kewajiban syariat, seperti perilaku tasawuf yang dilakukan oleh alHallaj (al-Hulu>l) dengan pernyataannya "ana al-Haq", Ibnu Araby (al-Ittiha $>d$ / manunggaling kawula gusti).

Terlepas dari beberapa definisi di atas, dikalangan warga NU sendiri terdapat beberapa definisi tentang Aswaja KH. Hasyim Asy'ari, merupakan Rais Akbar Nahdlatul Ulama'. Beliau memberikan tashawur (gambaran) tentang ahlussunnah waljamaah sebagaimana ditegaskan dalam alqanun al-asasi, bahwa faham ahlussunnah waljamaah versi Nahdlatul Ulama' yaitu mengikuti Abu Hasan al-asy'ari dan Abu Manshur al-Maturidi secara teologis, mengikuti salah satu empat madzhab fiqh (Hanafi, Maliki, Syafi'i dan Hanbali) secara fiqhiyah, dan bertashawuf sebagaimana yang difahami oleh Imam al-Ghazali atau Imam Junaid al-Baghdadi. ${ }^{25}$

Penjelasan KH. Hasyim Asy'ari tentang ahlussunnah waljamaah versi Nahdlatul Ulama' dapat difahami, pertama Penjelasan aswaja KH Hasyim Asy'ari, jangan dilihat dari pandangan ta'rif menurut ilmu Manthiq yang harus ja>mi' wa ma>ni' (مانع جامع) tapi itu merupakan juga gambaran yـengan akan lebih mudah kepada masyarakat untuk bisa mendaptkan pembenaran dan pemahaman secara jelas (يق تصــ).(Karena secara definitif tentang ahlussunnah waljamaah para ulama berbeda secara redaksional tapi muaranya sama yaitu ma $>$ ana alabi wa asha $>b i>$.

Kedua, penjelasan aswaja versi KH. Hasyim Asy'ari, merupakan implimentasi dari sejarah berdirinya kelompok ahlussunnah waljamaah sejak masa pemerintahan Abbasiyah yang kemudian terakumulasi menjadi firqah yang berteologi Asy'ariyah dan Maturidiyah, berfiqh madzhab yang empat dan bertashuwf al-Ghazali dan Junai al-Baghdadi. Ketiga, merupakan "Perlawanan" terhadap gerakan wahabiyah" (islam modernis) di Indonesia waktu itu yang mengumandangkan konsep kembali kepada al-quran dan as-sunnah, dalam arti anti madzhab, anti taqlid, dan anti TBC. (tahayyul, bid'ah dan khurafaat). Sehingga dari penjelasan aswaja versi NU dapat difahami bahwa untuk memahami al-Qur'an dan As-sunnah perlu penafsiran para Ulama yang memang ahlinya. Karena sedikit sekali kaum muslimin mampu berijtihad, bahkan kebanyakan mereka itu H. Hasyim Asy'ari merumuskan kitab Qanun Asasi (prinsip dasar), kemudian muqallid atau muttabi' baik mengakui atau tidak. ${ }^{26}$ Oleh karena itu maka K.H. Hasyim Asy'ari merumuskan kitab Qanun Asasi (prinsip dasar), dan juga kitab I'tiqad Ahlussunnah wal Jamaah. Kedua kitab tersebut, kemudian diejawantahkan dalam Khittah NU, yang dijadikan dasar dan rujukan sebagai warga NU dalam berpikir dan bertindak dalam bidang sosial, keagamaan dan politik.

Khusus untuk membentengi keyakinan warga NU agar tidak terkontaminasi oleh pahampaham sesat yang dikampanyekan oleh kalangan modernis, KH Hasyim Asy'ari menulis kitab Risa>lah Ablussunah wal Jama>'ah yang secara khusus menjelaskan soal bid'ah dan sunah. Sikap lentur NU sebagai titik pertemuan pemahaman akidah, fikih, dan tasawuf versi ahlusunah waljamaah telah berhasil memproduksi pemikiran keagamaan yang fleksibel, mapan, dan mudah diamalkan pengikutnya. ${ }^{27}$ Dalam perkembangannya kemudian para Ulama' NU di Indonesia menganggap bahwa Aswaja yang diajarkan oleh KH Hasyim Asy'ari sebagai upaya pembakuan atau menginstitusikan prinsip-prinsip tawassuth (moderat), tasha $>$ muh (toleran) dan tawa $>$ zun (seimbang) serta $t a^{\prime} a<d u l$ (Keadilan). Prinsip-prinsip tersebut merupakan landasan dasar dalam mengimplimentasikan Aswaja.

${ }^{25}$ Hasyim Asy'ari, Al-Qanun Al-Asasi; Risalah Ahlus Sunnah Wal Jama'ah, terjemah oleh Zainul Hakim, (Jember: Darus Sholah, 2006),16.

${ }^{26}$ Marwan Ja"efar, Ablussunnah Wal Jama'ab; Telaab Historis dan Kontekstual (Yogyakarta: LKiS, 2010), Cet. Pertama, 81.

${ }^{27}$ Said Aqil Siraj dalam Muhammad Idrus Ramli, Pengantar Sejarah Ablussunah Wal Jama'ah (Jakarta: Khalista, 2011), 26 
Seiring dengan derasnya perkembangan ilmu pengetahuan dalam berbagai bidang menuntut kita agar terus memacu diri mengkaji Ahlussunah Wal Jama'ah dari berbagai aspeknya, agar warga Nahdliyin dapat memahami dan memperdalam, menghayati dan mengejawantahkan arisan ulama al-salaf al-sa>lih yang berserakan dalam tumpukan kutub al-turast. Nahdlatul Ulama' dalam menjalankan paham ahlusunah waljamaah pada dasarnya menganut lima prinsip. Yakni, atTawa $>$ zun (keseimbangan), at-Tasa $>$ mub (toleran), at-Tawasuth (moderat), at-Ta'a $>d u l$ (patuh pada hukum), dan amar makruf nahi mungkar. Dalam masalah sikap toleran pernah dicontohkan oleh pendiri NU KH Hasyim Asy'ari saat muncul perdebatan tentang perlunya negara Islam atau tidak di Indonesia. Kakek mantan Presiden Abdurrahman Wahid itu mengatakan, selama umat Islam diakui keberadaan dan peribadatannya, negara Islam atau bukan, tidak menjadi soal. Sebab, negara Islam bukan persoalan final dan masih menjadi perdebatan. ${ }^{28}$

Lain dengan kebanyakan para Ulama' NU di Indonesia yang menganggap Aswaja sebagai upaya pembakuan atau menginstitusikan prinsip-prinsip tawasuth (moderat), tasa $>$ muh (toleran) dan tawa>run (seimbang) serta ta'a $>$ dul (Keadilan). Maka Said Aqil Shiroj dalam mereformulasikan Aswaja adalah sebagai metode berfikir (manhaj al-fikr) keagamaan yang mencakup semua aspek kehidupan manusia yang berdasarkan atas dasar moderasi, menjaga keseimbangan dan toleransi, tidak lain dan tidak bukan adalah dalam rangka memberikan warna baru terhadap cetak biru (blue print) yang sudah mulai tidak menarik lagi dihadapan dunia modern.

Hal yang mendasari imunitas (daya tahan) keberadaan paham Ahlus sunnah wal jama'ah adalah sebagaimana dikutip oleh Said Aqil Siradj, bahwa Ahlus sunnah wal jama'ah adalah:

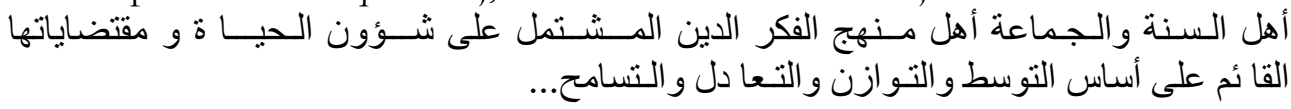

"Orang-orang yang memiliki metode berfikir keagamaan yang mencakup semua aspek kehidupan yang berlandaskan atas dasar-dasar moderasi, menjaga keseimbangan, keadilan dan toleransi". ${ }^{29}$

Prinsip dasar yang menjadi ciri khas paham Ahlus sunnah wal jama'ah adalah tawassuth, tawazzun, ta'adul, dan tasamuh; moderat, seimbang dan netral, serta toleran. Sikap pertengahan seperti inilah yang dinilai paling selamat, selain bahwa Allah telah menjelaskan bahwa umat Nabi Muhammad adalah ummat wasath, umat pertengahan yang adil (QS. Al-Baqarah: 143). Harus diakui bahwa pandangan Said Aqil Siradj tentang Aswaja yang dijadikan sebagai manhaj al fikr memang banyak mendapatkan tentangan dari berbagai pihak meskipun juga tidak sedikit yg memberikan apresiasi. Apalagi sejak kyai Said mengeluarkan karyanya yang berjudul "Ahlussunnah wal Jama'ah: Sebuah Kritik Historis".

Meskipun banyak sekali yang menentang pemikiran Said Aqil Siradj dalam memahami Aswaja dalam konteks saat ini, akan tetapi harus diakui bahwa paradigma yang digunakan Said Aqil Siradj dalam menafsiri Aswaja patut untuk dihormati. Karena yang dilakukan merupakan wujud tafsir dalam memahami Aswaja di era Globalisasi. Selain itu salah satu karakter Aswaja adalah selalu bisa beradaptasi dengan situasi dan kondisi, oleh karena itu Aswaja tidaklah jumud, tidak kaku, tidak eksklusif, dan juga tidak elitis, apa lagi ekstrim. Sebaliknya Aswaja bisa berkembang dan sekaligus dimungkinkan bisa mendobrak kemapanan yang sudah kondusif. Tentunya perubahan tersebut harus tetap mengacu pada paradigma dan prinsip al-sha $>$ lib wa alahslah.

Karena implementasi dari qaidah al-muba $>$ fadhah ala $>$ al-qa $>$ di $>m$ al-sha $>$ lih wa al-akhd $2 u$ bi al-jadi $>d$ al-aslah adalah menyamakan langkah sesuai dengan kondisi yang berkembang pada masa kini dan masa yang akan datang. ${ }^{30}$ Yakni pemekaran relevansi implementatif pemikiran dan

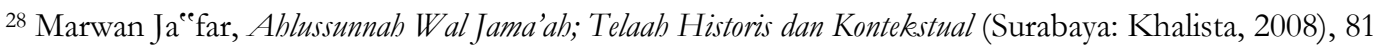

29 Said Aqil Siradj dalam Muhammad Idrus Ramli, Pengantar Sejarah Ablussunah Wal Jamaah (Surabaya: Khalista, 2011), 78.

${ }^{30}$ Said Aqil Siradj, Ahlussunnah wal Jama'ab; Sebuah Kritik Historis (Jakarta: Pustaka Cendikia Muda, 2008), 9. 
gerakan kongkrit ke dalam semua sektor dan bidang kehidupan baik, aqidah, syariah, akhlaq, sosial budaya, ekonomi, politik, pendidikan dan lain sebagainya. Semua itu dilakukan sebagaim wujud dari upaya untuk senantiasa melaksanakan ajaran Islam dengan sungguh-sungguh.

Adalah sosok KH. Said Agil Siradj yang telah berhasil melakukan kontekstualisasi nalar Aswaja al-Nahdliyah. Menurutnya, Ahlussunnah Waljamaah adalah orang-orang yang memiliki metode berfikir keagamaan yang mencakup semua aspek kehidupan yang berlandaskan atas dasardasar moderasi, menjaga keseimbangan, dan toleransi. Baginya Ahlussunnah Waljamaah harus diletakkan secara proporsional, yakni Ahlussunnah Waljamaah bukan sebagai mazhab, melainkan sebuah manhaj al-fikr (pendekatan berpikir tertentu) yang digariskan oleh sahabat dan para muridnya, yaitu generasi tabi'in yang memiliki intelektualitas tinggi dan relatif netral dalam menyikapi situasi politik ketika itu. Namun harus diakui bahwa kelahiran Ahlussunnah Waljamaah sebagai manhaj al-fikr tidak terlepas dari pengaruh tuntutan realitas sosio-kultural dan sosiopolitik yang melingkupinya. ${ }^{31}$

Dalam merespon berbagai persoalan baik yang berkenaan dengan persoalan keagamaan maupun kemasyarakatan, Nahdlatul 'Ulama memiliki manhaj Ahlusunnah wal Jama'ah yang dijadikan sebagai landasan berpikir Nahdlatul 'Ulama (Fikrah Nabdliyah). Adapun ciri-ciri dari Fikrah Nahdliyah antara lain:

a. Fikrah Tawassuthiyah (pola pikir moderat), artinya Nahdlatul 'Ulama senantiasa bersikap tawa>zun (seimbang) dan $i$ 'tida $>l$ (moderat) dalam menyikapi berbagai persoalan.

b. Fikrah Tasa>mubiyyah (pola pikir toleran), artinya Nahdlatul 'Ulama dapat hidup berdampingan secara damai dengan berbagai pihak lain walaupun aqidah, cara pikir, dan budayanya berbeda.

c. Fikrah Ishla $>$ biyyah (pola pikir reformatif), artinya Nahdlatul 'Ulama selalu mengupayakan perbaikan menuju kea rah yang lebih baik (al-ishla $>$ h ila $>$ ma $>$ buwa al-ashlah).

d. Fikrah Tathawwuriyah (pola pikir dinamis), artinya Nahdlatul 'Ulama senantiasa melakukan kontekstualisasi dalam merespon berbagai persoalan.

e. Fikrah Manhajiyah (pola pikir metodologis), artinya Nahdlatul 'Ulama senantiasa menggunakan kerangka berpikir yang mengacu kepada manhaj yang telah ditetapkan oleh Nahdlatul ‘Ulama.

\section{Pesantren dan Pendidikan Islam: Mengokohkan kembali Nasionalisme Religius}

Jika di atas penulis lebih condong membahas bagaimana Muhammadiyah menanggapi gerakan-gerakan transnasionalisme, maka di bagian ini penulis ingin mengungkapkan bagaimana semestinya kondisi lembaga pendidikan dan peranannya dalam membangun masyarakat yang moderat, inklusif, toleran, dan multikultural. Pesantren merupakan institusi pendidikan yang berperan secara intensif dalam penyebaran Islam di Nusantara khususnya di pulau Jawa, bahkan menjadi media utama gerakan Islam dalam pembinaan moral bangsa Indonesia. ${ }^{32}$ Karakter pesantren yang akomodatif terhadap pola kehidupan masyarakat setempat dalam melakukan transformasi sosio-kultural, bahkan format pendidikan pesantren dipandang sebagai islamisasi lembaga pendidikan yang telah ada sejak masa Hindu-Budha, ${ }^{33}$ karena ada kemiripan antara pesantren dengan tradisi yang ada pada padepokan dalam tradisi Hindu-Budha; yaitu konsentrasi pendidikannya pada pembelajaran agama, gurunya tidak digaji, adanya penghormatan yang besar terhadap guru, dan letaknya yang berada di luar perkotaan. ${ }^{34}$ Posisi pesantren yang dipandang sebagai kelanjutan dari lembaga pendidikan Jawa kuno yang bernama pawiyatan, di mana Ki Ajar sebagai pengajar dan Cantrik sebagai murid tinggal dalam satu komplek dan di sanalah terjadi

\footnotetext{
31 Achmad Siddiq, Khittah Nabdliyyah, (Surabaya, Khalista, Cet. 3, 2005), 30.

32 Arif, Pendidikan Islam,165. Lihat juga Zamakhsyari Dhofier, Tradisi Pesantren.. 62

33 Madjid, Pendidikan Pesantren, 3.

${ }^{34}$ Karel A. Stenbrink, Pesantren Madrasah Sekolah: Pendidikan Islam dalam Kurun Modern, Jakarta: LP3ES,
} 1994), 20-21. 
proses belajar mengajar ${ }^{35}$, maka sangat beralasan bila pendidikan pesantren dipandang sebaga institusi yang menjadi salah satu kekuatan dalam mempercepat penyebaran Islam di Indonesia secara damai.

Ada tiga karakter utama budaya pesantren yang lebih mendekati ideologi perdamaian. Pertama, Modeling. Karakter ini dalam terma keislaman dapat diidentikkan dengan uswab b\}asanah, dimana proses transformasi nilai tidak hanya menggunakan bahasa lisan melainkan melalui percontohan dalam bentuk tingkah laku. Para santri dan masyarakat melakukan proses identifikasi diri pada Kyai yang dijadikan tokoh dan panutan dalam berprilaku. Pola modeling dalam pendidikan pesantren ini, mendapat tempat di masyarakat Jawa karena ada kesesuaian dengan sistem nilai Jawa yang telah lama mengakar dalam budaya Jawa; yaitu paternalism dan patron-client relation. ${ }^{36}$

Kedua, Cultural maintenance. Pendidikan pesantren menggambarkan adanya kontinuitas budaya, tanpa melakukan perombakan fondamental terhadap budaya lokal tapi tetap bersandar pada ajaran dasar Islam. Para Kyai menjadi agent of social change lebih menggunakan pendekatan kultural, bukan politik struktural apalagi tindakan arogansi dan kekerasan. Apa yang dilakukan para Kyai melalui pendidikan pesantren bukan intervensi budaya melainkan perembesan budaya atau akulturasi. ${ }^{37}$ Pesantren yang menjadi pusat proses dialogis antara tradisi lokal dan ajaran Islam, melalui proses akulturasi, asimilasi, dan adaptasi tradisi lokal yang animis dan nilai-nilai Islam, telah menghasilkan tradisi baru Islam Indonesia yang selalu membawa sikap harmonis dalam strategi pendidikan dan pengembangannya. ${ }^{38}$ Karakter kedua ini, tercermin pula dalam penggunaan refernsi utama pendidikan pesantren, yang tetap mempertahankan karya klasik atau yang disebut dengan Kitab Kuning. Penggunaan Kitab Kuning dalam pendidikan pesantren yang ditransmisikan dari generasi ke genarasi, menunjukkan adanya upaya pendidikan pesantren untuk melestarikan warisan budaya Islam periode awal dan pertengahan. ${ }^{39}$

Ketiga, Budaya Keilmuan Yang Tinggi. Menuntut ilmu di pesantren tidak dikenal batasan umur, dan batasan waktu. Tidak jarang seseorang yang sudah beranak cucu, masih belajar di Pesantren terutama dalam kegiatan pengajian Ramad\{an atau yang dikenal dengan istilah pengaiian kilatan. Dalam tradisi pesantren juga dikenal santri kelana, yaitu santri yang melakukan rib Jlah dalam pencarian ilmu dari satu pesantren ke pesantren lainnya, bahkan tidak sedikit dari komunitas pesantren yang melakukan rib\} lah dalam pencarian ilmu sampai ke luar negeri. ${ }^{40}$

Dalam prespektif kebangsaan, Pesantren hadir sebagai pusat pendidikan kebangsaan, dengan mendidik santri dan anak bangsa lainnya mandiri tidak hanya dalam ekonomi dan politik, melainkan mandiri juga dalam bidang kebudayaan dan pengetahuan. Pesantren mengembangkan pendidikan kebangsaan melalui pembiasaan hidup dalam kebersamaan baik dalam asrama, maupun di luar asrama dengan anak-anak bangsa tanpa memperhatikan latar suku, bahasa, bahkan agamanya. Mereka dididik untuk saling berinteraksi secara harmonis di antara berbagai komunitas bangsa yang heterogin. Dan apabila ada perselisihan, mereka diminta berdamai dengan mediasi para Ulama pesantren. ${ }^{41}$

Dari pesantren, para pegiat pergerakan belajar tentang non kooperatif, menolak kerjasama dengan Belanda. Sikap pesantren untuk menjadi dirinya sendiri, kesediaan untuk hidup bersahaja dalam kesederhanaanya, pembiayaan pendidikan dibangun di atas kekuatan sumber daya alam yang ada disekitarnya, dari hasil pertanian, perkebunan dan peternakan, tidak memandang penting

\footnotetext{
35 Haidar Putra Daulay, Sejarah Pertumbuhan, 21.

36 Abdurrahman Mas'ud, Memahami Agama Damai, xix-xx.

37 Ibid, xxii

${ }^{38}$ Badrus Sholeh, Dinamika Baru Pesantren, dalam Badrus Sholeh (Ed), Budaya Damai, xxviii.

39 Abdurrahman Mas'ud, Memahami Agama Damai, xxiii.

40 Abdurrahman Mas'ud, Memahami Agama Damai, xxiii-xxiv. Lihat juga Abuddin Nata, Sejarah Sosial Intelek.tual Islam dan Institusi Pendidikannya (Jakarta: Raja Grafindo Persada, 2012), 310-311.

41 Ahmad Baso, Pesantren Studies.. 2a, 50-51.
} 
dana subsidi pemerintah kolonial, Ki Hajar Dewantara sebagaimana dikutip Ahmad Baso, memandang sikap pesantren tersebut sebagai bentuk kemerdekaan pesantren. ${ }^{42}$

Pesantren dipandang oleh pegiat peregerakan nasional, sebagai lembaga pendidikan yang banyak memberikan kontribusi dalam membentuk sifat dan karakter pengajaran nasional yang membedakan dengan pengajaran kolonial. Kedekatan Pesantren dengan masyarakat paling bawah, memperkaya pendidikan kultural, kerohanian masyarakat, memupuk solidoritas dan mengukuhkan semangat kebangsaan yang bertumpu pada tiga nilai dasar; persatuan, kemandirian dan kemerdekaan. ${ }^{43}$ Pendidikan pesantren dengan sistem asrama (pondok), berhasil mempersatukan dan merekatkan hubungan anak-anak bangsa dari semua lapisan masyarakat, baik anak petani, anak saudagar, anak bangsawan, semua berkumpul dalam ikatan nilai persamaan dan kebersamaan dalam kepemimpinan seorang kyai yang sederhana dan merakyat, sehingga pada saat mereka kembali ke masyarakatnya dengan profesi yang beraneka ragam, tetap merasa dalam kesatuan karena perikatan lahir dan batin yang tertanam sejak ada dalam pendidikan pesantren. Sehingga kehidupan bangsa dari lapisan apapun tidak tercerai berai, tidak terpisah satu sama lainnya. ${ }^{44}$

Pada masa pergolakan nasional di tahun 1930 an, pada saat itu aktivitas pergerakan nasional hidup di balik tembok-tembok pesantren, para aktivis pergerakan menjadikan pesantren sebagai oase perlindungan dari kejaran polisi Belanda. Pesantren tidak hanya menjadi pusat pendidikan kebangsaan, melainkan menjadi basis pergerakan nasional dalam membangun semangat kebangsaan dalam melawan segala bentuk penjajahan. ${ }^{45}$ Membaca fakta sosial keterlibatan pesantren dalam pergerakan nasional melawan penjajahan, dapat dikatakan bahwa pesantren memiliki andil dalam mengantarkan Indonesia Merdeka, Dan bisa dipahami apabila sampai saat ini, komunitas pesantren terus bergerak dalam mengisi kemerdekaan dalam berbagai bidang atau aspek pembangunan, tidak hanya dalam bidang pendidikan, dakwah, dan sosial yang menjadi khittah perjuangannya, melainkan juga di bidang politik yang merupakan medan baru sebagai bentuk respon pesantren terhadap situasi yang mengitarinya, dan sikap tanggunjawab pesantren terhadap eksistensi masyarakat bangsa di Nusantara ini.

\section{Terminologi Gerakan Transnasional Islam}

Gambaran utuh mengenai terminologi gerakan Trans-nasional, sebagai hasil kajian ilmiah, memang sulit untuk dilacak. Bahkan Masdar Hilmy hanya menyebuntukan bahwa terminologi Trans-nasionalisme hanya merupakan ungkapan dari dua tokoh gerakan Islam terbesar di Indonesia; yakni KH. Hasyim Muzadi sebagai mantan ketua PBNU dan Syafi'i Ma'arif mantan ketua Muhammadiyah ${ }^{46}$. Terminologi Trans-nasionalisme memang sempat diungkapkan oleh KH. Hasyim Muzadi untuk menggambarkan pelbagai tipologi gerakan baru yang mulai menyebar di Indonesia yang disupport oleh kekuatan di luar negeri. Lebih tepatnya beliau ingin menyebuntukan bahwa radikalisme yang terjadi di Indonesia terjadi karena dibantu oleh beberapa negara-negara maju, dan tidak murni keinginan orang Islam-Indonesia ${ }^{47}$. Sedangkan Syafi'i Maarif memasukkannya dalam kalimat bukunya yakni "....sorotan berikutnya atas HTI, berbeda dengan MMI yang bercorak Indonesia, HTI adalah gerakan politik. Islam Trans-nasional yang digagas oleb Taqiyuddin An$\mathrm{Nabhan}^{48}$. Namun, beliau tidak menafsirkan organisasi apa saja yang dimasukkan dalam kategori gerakan Trans-nasional.

Dalam upayanya menjelaskan terminologi Trans-nasionalisme Islam sebagai nomenclature, Masdar Hilmy meminjam pengertian yang diungkapkan oleh J.R Bowen yang mencakup tiga hal;

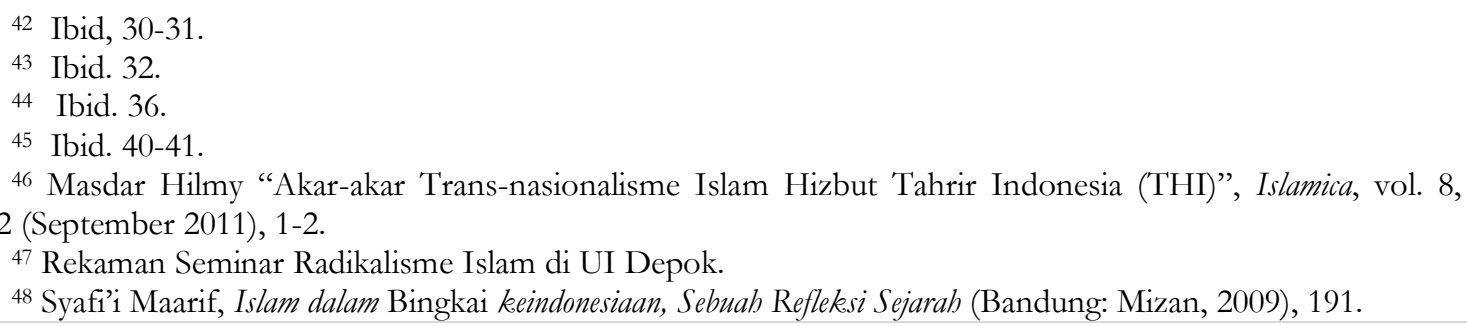


(a) pergerakan demografis. (b) lembaga keagamaan Trans-nasional. (c) perpindahan gagasan atau ide. ${ }^{49}$ Pengertian pertama bermakna bahwa Trans-nasionalisme berarti pergerakan lintas negara. Terma kedua memiliki makna perangkat kelembagaan yang memiliki jejaring internasional. Sedangkan yang terakhir adalah perpindahan idea tau gagasan dari kelompok atau individu dari negara yang satu ke negara yang lain.

Jikalau melihat makna terminologis Trans-nasionalisme dalam arti yang demikian maka ada kesamaan persepsi pula di khalayak umum bahwa gerakan Trans-nasionali atau Transnasionalisme adalah sebuah gerakan yang melintasi batas negara (nation), berbasis pada umat Islam di seluruh dunia, didominasi oleh pemikiran skriptualis, radikal, fundamental, dan bergagasan berbeda dengan konsep nation-state ${ }^{50}$. Sebagai contohnya adalah kelompok gerakan Ikhwanul Muslimin, gerakan yang sekarang memegang kekuasaan di Mesir ini, ingin mengembalikan kekuatan Islam sebagai basis politik dan keluar dari hegemoni konsep demokrasi yang dikembangkan masyarakat Barat.

Dalam bingkai pemikiran G. Fealy dan Bubalo menyebutkan bahwa ada upaya 'deteritorialisasi' Islam agar bisa menembus pada dimensi global. ${ }^{51}$ Deteritorialisasi yang dimaksudkan juga memiliki kesamaan dengan pandangan Trans-nasionalisme, dimana sebuah gerakan bekerja melalui ideologi dan jejering yang sangat luas dan melintasi dari teritori kenegaraan tertentu. Target utama dari gerakan deteritorialisme ini adalah mengubah budaya asli negara muslim setempat, dengan pandangan baru yang dianggap dimiliki oleh Islam murni. Artinya, umat Islam yang berbeda dengan pandangan kelompok gerakan ini dianggapnya salah, serta tidak menerima akulturasi kebudayaan Islam dengan local wisdom yang dimiliki negara Islam tertentu.

Diakui atau tidak, Trans-nasionalisme, Islam Trans-nasional, atau gerakan Islam Transnasional sudah berwujud dan banyak ditemukan. Meskipun secara keilmiahan terminologi tersebut berbeda-beda disebutnya. Islam, sebagaimana wujudnya, memang merupakan agama global yang tidak hanya dianut oleh negara tertentu. Persinggungan nilai dan global akan terus terjadi meskipun ditanggapi secara berbeda-beda. Meminjam istilah, Fethullah Gulen Islam, melalui nilai universalismenya, memang tidak bisa dimiliki oleh kalangan tertentu. Iran memiliki tradisi sendiri untuk merayakan tauladannya, 'Ali bin Abi Tholib, sedangkan di negara lain mereka juga punya tradisi lain yang dianggapnya merupakan bagian dari Islam, begitu juga dengan Turki, yang dulunya dibangun di atas narasi sufisme ${ }^{52}$.

\section{Bentuk-Bentuk Organisasi Transnasional Islam di Indonesia}

a. Hizbut Tahrir

Hizbut Tahrir, sebagaimana dilansir dalam situs Indonesianya, adalah gerakan yang berdiri pada tahun 1953 di al-Quds (Baitul Maqdis) Palestina. Gerakan ini menitik beratkan pada perjuangan penegakan Khila $>$ fah Isla $>$ miyah sebagai sistem politik dan penegakan nilainilai keIslaman ${ }^{53}$. Gerakan ini dikomandoi pertama kali Taquidin an-Nabhani, seorang ulama' alumni Mesir. Hizbut Tahrir saat ini sudah berkembang di berbagai dunia, termasuk di Indonesia dengan nama Hizbut Tahrir Indonesia.

Hizbut Tahrir di Indonesia mulai masuk pada tahun 1980-an dengan merintis dakwah di beberapa kampus, perumahan, dan hingga saat ini mereka sudah memiliki kader dan produk lembaga pendidikan sendiri ${ }^{54}$. Dalam buku manifestonya, HTI mendeklare bahwa kelompok

49 Masdar Hilmy "Akar-akar Trans-nasionalisme Islam Hizbut Tahrir Indonesia (THI)", Islamica, vol. 8, Nomor 2 (September 2011), 2.

50 Ibid., 6.

51 Situs Resmi Hizbut Tahrir Indonesia, http://hizbut-tahrir.or.id/tentang-kami/ diakses 6 Pebruari 2017

${ }^{52}$ Fethullah Gulen, Love and Tolerance (New Jersey: Tughra Book, 2009), 223.

${ }^{53}$ Situs Resmi Hizbut Tahrir Indonesia, http://hizbut-tahrir.or.id/tentang-kami/. Akun ini akhirnya ditutup setelah pemerintah membubarkan HTI melalui Peraturan Pemerintah Pengganti Undang- Undang nomor 2 tahun 2017.

$$
{ }^{54} \text { Ibid. }
$$


ini akan berjuang demi tegaknya khilafah, dan persatuan umat Islam seluruh dunia. ${ }^{55}$ Karena berlandaskan pada sistem khilafah, politik pendidikan yang mereka akan laksanakan adalah pendidikan berbasis Islam, yang menyediakan pendidikan untuk semua kalangan tanpa adanya diskriminasi. ${ }^{56}$

Lebih lanjut dijelaskan, pendidikan mestinya diarahkan terbentuknya kepribadian muslim anak didik dan membina mereka agar menguasai ilmu pengetahuan tekhnologi serta thaq \{\}$a>$ fah Islam. Pendidikan juga mesti menjadi media dakwah dan menyiapkan peserta didik agar kelak menjadi kader umat menjadi bagian dalam memajukan masyarakat ${ }^{57}$. Berdasarkan alenia terakhir ini, pendidikan selain menjadi alat kemajuan dan kepentingan bangsa, juga menjadi bagian dari strategi gerakan untuk terus menegakkan khila $>$ fah, sebagaimana yang sudah didengungkan lebih awal.

Dalam jarum jam perjalanannya, setidaknya Hizbut Tahrir lebih dikenal sebagai gerakan yang ingin menegakkan Kbila $>f a h$ Isla $>$ miyah melalui gerakan politik. Namun, ada aspek lain yang 'mungkin' dianggap berbeda dengan beberapa gearakan yang ada sebelumnya. Misalnya dari segi aqidah. Gerakan ini ditengarai lebih condong pada aqidah mu'tazilah. Pasalnya, tokoh mereka sendiri menyebutkan :

"Aqidah seorang muslim harus bersandar kepada akal atau pada sesuatu yang telah terbukti dengan akal atau yang datang dari sumber berita yang yakin dan pasti (qat\}'i>), yaitu apa-apa yang yang telah ditetapkan oleh Al-Qur'an dan hadits qoth'i yaitu hadits yang mutawatir. Apa saja yang tidak terbukti dengan kedua jalan tadi, yaitu akal serta nash Al-Qur'an dan hadits mutawatir, haram baginya untuk mngimaninya (menjadikannya sbagai aqidah). Sebab aqidah tidak boleh dambil kecuali dengan kepastian. Mereka memanfaatkan istlah-istilah fiqhiah qat\}' $i>$ thubut (jelas dan pasti sumbernya dari Nabi), z\}anny thubut (masih belum jelas sumbernya dari Nabi), qat $\}^{\prime} i>$ dala>lab (pasti dan jelas penunjukannya) dan z\}anny dala>lah (masih belum jelas penunjukannya) untuk menuju pada hal-hal yang menyimpang. Mereka berkata: Tidak boleh bagi seorang muslim membangun aqidahnya kecuali berdasarkan dalil yang qot\}'i> thubut dan $z$ \} anny thubut. Kalau cuma salah satu maka tidak bisa. Sehingga haditshadits ahad tentang aqidah walaupun $q a t\}^{\prime} i>$ dala $>$ lab mereka tolak karena tidak mutawatir" ${ }^{58}$

Selain itu, keberadaan Hizbut Tahrir yang juga menjadi perbicaraan umat Islam di Indonesia adalah aspek penolakan mereka dengan kepentingan ideology-ideologi Barat. Jikalau dilihat dari beberapa tulisan-tulisan yang disebarkan pada setiap hari Jum'at, concern mereka lebih banyak menyalahkan sistem demokrasi yang sedang dijelankan oleh banyak negara Islam. Bagi mereka, garis politik demokratis membuka kran terhadap penistaan nilainilai keIslaman. ${ }^{59}$

Setidaknya itulah sedikit gambaran mengenai Hizbut Tahrir di Indonesia. Alasan pengkategorian kelompok ini dengan gerakan Trans-nasional dikarenakan gerakan mereka tidak murni berasal dari lingkup historisitas keindonasiaan. Sebagaimana disebutkan oleh Syafi'i Maarif, bahwa HTI adalah gerakan yang lahir di luar konteks Indonesia, meskipun gerakan mereka tidak mengarah pada aspek radikalisme dan anarkhisme ${ }^{60}$. HTI, sebagaimana

\footnotetext{
55 Ibid.

56 Ibid.

${ }^{57}$ Ibid.

58 Abu Ihsan al-Atsyi Aqidah Hižbut Tahrir Indonesia http://www.salafyoon.net/manhaj/hizbut-tahrir.html

59 Dalam pengantar salah satu bukunya, Abdul Qadim Zallum, menulis: "al-di>muqra $>$ thiyyah al-lati> sawaqaha $>$ al-gharb al-ka $>$ fir ila $>$ bila $>d$ al-muslimi $>n$ huwa nidha $>m$ kufr", bahwa demokrasi yang dipasarkan oleh Barat yang kafir adalah sistem kufur. Selengkapnya, lihat: Abdul Qadim Zallum, al-Dimuqra $>$ thiyyah Nidha $>m$ Kufr Yahrumu Akhdzuha $>$ aw Tathbi $>$ quha $>$ aw al-Da'watu Ilaiba $>$, Mansyurat Hizb al-Tahrir, ttp. tth., 2.
} 
dijelaskan Masdar Hilmy, dikatakan bagian Trans-nasionalisme kareka adanya traveling idea dari sebuah gerakan di luar Indonesia atau ini bagian dari teori diaspora yang menganggap bahwa ada asimilasi kebudayaan dari penduduk pendatang yang ada di Indonesia. ${ }^{61}$

b. Ikhwanul Muslimin

Salah satu dari berbagai gerakan keagamaan yang muncul di Mesir pada awal abad dua puluh-an masehi adalah gerakan Ikhwanul Musliimin. Ikhwanul Muslimin disebut juga alIkhwan al-Muslimin, tema yang sering digunakan dalam bahasa inggris untuk gerakan ini adalah "muslim brothers" atau "muslim bretbren", mengandung pengertian muslim bersaudara atau persaudaraan Islam di Mesir. Pendirian gerakan ini dipreakarsai oleh Hasan al-Bannaseorang figure kharismatik, lahir di Mesir pada tahun 1906. Hasan al-Banna dilahirkan tepatnya pada bulan Oktober 1906 di al-Mahmu>diyah, sebuah kota kecil di propensi Buhairoh, kira-kira 9 mil dari arah barat daya kota Kairo. Hasan al-Banna adalah anak tertua dari lima bersaudara. Al-Banna kecil dibesarkan ditengah-tengah keluarga agamis, damai dan tentram serta sangat konsen terhadap ilmu pengetahuan.

Beberapa guru, disamping ayah kandungnya Ahmad Abdurrahman al-Banna, yang dikenal dengan si tukang arloji dan penjilid buku, dan memiliki beberapa kitab agama terutama dibidang ilmu hadis, telah memiliki peran cukup dominan terhadap pembentukan karakter dan perkembangan pemikirannya sehingga kelak ia begitu disegani tidak hanya di kalangan masyarakat Mesir, bahkan masyarakat luas di muka bumi. Ayah al-Banna tergolong berharta dan dihormati, lahir di Distrik Syamsiroh tepatnya dibagian fuh. Shaykh Ahmad juga akrab dengan sebagian ulama. Ketika penduduk di desanya membangun masjid, ia diminta untuk menjadi imam shalat jum'at pertama. Ia memiliki perpurstakaan dengan berbagai literature agama, seni, dan ilmu pengetahuan lainnya.

Al-Banna melalui pendidikan formalnya, ketika usianya menginjak delapan tahun disekolah Kuttab, yaitu Madra>sah al-Rashad al-Di>ni>yah -lembaga yang dikelola oleh syaikh Muhammad Zahran- seorang guru yang dikenal sangat pandai, berakhlak baik dan memiliki semangat jihad tinggi, walaupun secara formal sebelum diberi gelar ulama. Lembaga yang di kelolanya didirikan pada tahun 1915 bertujuan untuk mendidik pemuda-pemuda desa dan pelosok pada masa itu, dalam lembaga ini juga memiliki kualitas yang sama dengan lembaga yang sudah maju dalam hal materi pelajaran dan metode pengajaran. Mata pelajaran umum juga diajarkan. Cukup banyak ilmu pengetahuan yang diperolehnya, selain perlajaran dikelas (badist naba>my, insha>', qawa>'id, mah\}fu>z\}at, imla>', mut\}a>la'ab) yaitu metode menghafal, memahami hadis dan syair, kedisiplinan dan motivasi belajar serta hubungan erat guru-murid (subbah al-usta $>$ d).

Selama kurang lebih empat tahun di madrasah ini, al-Banna melanjutkan studinya ke jenjang yang lebih tinggi, yaitu disekolah menengah pertama di Mahmudiyah, sambil belajar menghafal al-Qur'an di bawah bimbingan ayahnya. Ia sudah hafal al-Qur'an ketika usianya menginjak 14 tahun. Di usia yang cukup belia ini, al-Banna melibatkan diri dalam beberapa organisasi keagamaan. Seperti di Jam'iyah al-Akhla $>q$ al-Ada $>$ biyah, dan ia pun ditunjuk menjadi ketua.

c. Wahabi

Gerakan Wahabi dilancarkan mulai abad ke-18, dan dalam waktu singkat telah tersebar luas ke penjuru dunia Islam. Pada awal abad ke-20, gerakan ini bangkit kembali dengan hasil gemilang yang disebarluaskan oleh murid Abdul Wahhab. Tampaknya kesuksesan gerakan ini banyak didukung oleh sifat keras dan tidak toleran yang diperlihatkan gerakan ini. ${ }^{62}$

Muhammad bin Abdul Wahhab, pionir Gerakan Wahabi, melihat bahwa kemurnian tauhid, pertama, telah dirusak oleh praktek ajaran tarekat. Banyak orang muslim pergi ke makam wali dan syekh tarekat yang mereka anggap sebagai perantara kepada Allah S.W.T.;

61 Ibid.

${ }^{62}$ Taufik Abdullah (ed.), Ensiklopedi Tematis Dunia Islam volume 5 Asia Tenggara (Jakarta: PT. Ichtiar Baru van Hoeve, 2005), 351. 
kedua, tauhid telah dirusak oleh paham animism dengan bentuk menyembah pohon dan benda lainnya. Abdul Wahhab, pengikuti setia Ibnu Taimiyah ini berpendapat jika muslim menyembah selain Allah s.w.t. dan meminta pertolongan bukan kepada Allah s.w.t., melainkan kepada syekh, wali atau kekuatan ghaib, maka ia menjadi musyrik, dan bahkan darahnya halal. ${ }^{63}$

Dengan mengangkat bendera "purifikasi", Wahabi memperluas jangkauan pemikirannya ke berbagai belahan dunia, termasuk Indonesia. Wajah puritan Wahabi semakin tampak jelas ketika berhadapan dengan tradisi dan budaya masyarakat Indonesia yang dinilai sesat dan berlumuran bid'ah bahkan syirik.

d. Syi'ah

Kajian tentang Syi'ah di Indonesia, telah dilakukan oleh sejumlah ahli dan pengamat sejarah, sebagian besar diantaranya berkesimpulan bahwa orang-orang Persia -yang pernah tinggal di Gujarat- yang berpaham Syiahlah yang pertama kali menyebarkan Islam di Indonesia.

Bahkan dikatakan Syi'ah pernah menjadi kekuatan politik yang tangguh di nusantara. M Yunus Jamil dalam bukunya Tawarikh Raja-raja Kerajaan Aceh (1968) menulis kerajaan Islam yang pertama berdiri di Nusantara adalah Kerajaan Peureulak (Perlak) yang didirikan pada 225H/845M. Pendiri kerajaan ini adalah para pelaut-pedagang Muslim asal Persia, Arab dan Gujarat dan mengangkat seorang Sayyid Maulana 'Abd al-Aziz Syah, keturunan Arab-Quraisy, yang menganut paham politik Syi'ah, sebagai sultan Perlak.

Agus Sunyoto, staf Lembaga Penerangan dan Laboratorium Islam (LPII) Surabaya yang dipimpin Dr Saleh Jufri, seperti dilaporkan Majalah Prospek (10 Nopember 1991), melalui penelitiannya menyimpulkan, bahwa Shaykh 'Abd al-Ra'u>f Al-Sinkly, salah seorang ulama besar nusantara asal Aceh pada abad ke-17, adalah pengikut dan penggubah sastra Syi'ah. Ia pun setelah melakukan penelitian terhadap kuburan-kuburan di Jawa Timur, berkesimpulan bahwa dari segi fisik dan arsitekturnya itu adalah kuburan-kuburan orang Syi'ah.

Bahkan Agus Sunyoto lewat bukti-bukti sejarah, berspekulasi, sebagian besar dari Walisongo adalah ulama Syi'ah. Dengan tegas ia menulis, Syekh Maulana Malik Ibrahim, guru dari semua sunan wali songo adalah Syiah. ${ }^{64}$

Dalam masyarakat NU, pengaruh Syi'ah pun cukup kuat di dalammya, Dr Said Agil Siraj, Wakil Katib Syuriah PBNU secara terang mengatakan, "Harus diakui, pengaruh Syi'ah di NU sangat besar dan mendalam. Kebiasaan membaca Barzanjy atau Diba > $i$ yang menjadi ciri khas masyarakat NU misalnya, jelas berasal dari tradisi Syi'ah".

$\mathrm{KH}$ Abdurrahman Wahid bahkan pernah mengatakan bahwa Nahdatul Ulama secara kultural adalah Syi'ah. Ada beberapa shalawat khas Syi'ah yang sampai sekarang masih dijalankan di pesantren-pesantren. Ada wirid-wirid tertentu yang jelas menyebutkan lima keturunan Ahlul Bait. Kemudian juga tradisi ziarah kubur, lalu membuat kubah pada kuburan. Itu semua tradisi Syi'ah. Tradisi itu lahir di Indonesia dalam bentuk mazhab Syafi'i padahal sangat berbeda dengan mazhab Syafi'i yang dijalankan di negara-negara lain. ${ }^{65}$

Kiai Abdurrahman Wahid atau Gus Dur pernah menyebut bahwa salah satu pengaruh tradisi Syiah dalam corak keIslaman di Indonesia adalah praktik nyanyian (biasa disebut juga pujian) menjelang salat yang biasa dipraktikkan di kalangan warga nahdliyyin (NU). Nyanyian itu berisi pujian untuk "abl al-bayt" atau keluarga Nabi, istilah yang sangat populer di kalangan Syiah.

Ritus-ritus Tabut di Bengkulu dan Sumatera dan Gerebek Sura di Jogjakarta dan Ponorogo adalah ritus teologi Syiah yang datang dari Gujarat-Persia. Doktor Muhammad Zafar Iqbal dalam bukunya, Kafilah Budaya, meruntut berbagai fakta tentang adanya

\footnotetext{
${ }^{63}$ Ibid., 351.

${ }^{64}$ Agus Sunyoto, Walisongo (Yogyakarta: Serambi, 2010), 78.

65 Agus Sunyoto, Walisongo, 90.
} 
pengaruh-pengaruh tradisi Syiah dan Iran di tanah air terutama bagi masyarakat Minangkabau yang masih terjaga sampai kini.

Perguruan Tinggi pertama di Aceh bernama Universitas Syiah Kuala, menunjukkan fakta lainnya. Universitas yang disingkat Unsyiah yang diresmikan berdirinya oleh Presiden Soekarno tahun 1959 menunjukkan bahwa idiom Syiah telah sangat dikenal masyarakat.

Karena kuatnya unsur-unsur Syiah dalam corak keIslaman di Indonesia inilah, hubungan antara Sunni dan Syiah, sejak dahulu, berlangsung dengan cukup bersahabat. Pada saat Gus Dur memimpin ormas Islam terbesar di Indonesia, yakni Nahdlatul Ulama (NU), sejak 19841999, hubungan antara kalangan NU dan Syiah juga cukup bersahabat. ${ }^{66}$

Namun yang patut di sesalkan adalah adanya sebagian besar kalangan salafi di Indonesia yang menampakkan antipati yang mendalam terhadap kelompok Syiah. Kelompok ini yang sangat dipengaruhi oleh doktrin Wahabisme dan sekarang juga tumbuh menjamur di beberapa kota, terutama di Jakarta. Bagi mereka, Syiah dianggap sebagai kelompok yang sudah keluar dari Islam. Dan terus menyebarkan fitnah di tengah masyarakat awam dan menciptakan perselisihan antara umat Islam.

e. Jama'ah Islamiyah

Jamaah Islamiyah adalah sebuah kelompok Islam yang beroperasi secara rahasia. Jamaah Islamiyah adalah sebuah organisasi militan Islam di Asia Tenggara yang berupaya mendirikan sebuah negara Islam raksasa di wilayah negara-negara Indonesia, Singapura, Brunei, Malaysia, Thailand dan Filipina. Pemerintah Amerika Serikat menganggap organisasi ini sebagai organisasi teroris, sementara di Indonesia organisasi ini telah dinyatakan sebagai "korporasi terlarang".

Jemaah Islamiyah dicurigai melakukan aksi pengeboman Bali 2002 pada tanggal 12 Oktober 2002. Dalam serangan ini, pelaku bom bunuh diri dari Jemaah Islamiyah disebutsebut menewaskan 202 orang melukai beberapa lainya di sebuah nightclub. Setelah serangan ini, Departemen Luar Negeri Amerika Serikat menyatakan Jemaah Islamiyah sebagai pelakunya dan menyatakannya sebagai Organisasi Teroris Asing. Jemaah Islamiyah juga dicurigai melakukan pengeboman Zamboanga, pemboman Metro Manila, dan pemboman kedutaan Australia 2004 di Jakarta. Bahkan dinyatakan bahwa Jamaah Islamiyah pertama kali melibatkan dirinya sebagai kelompok sel teror yang menyediakan dukungan keuangan dan logistik bagi operasi Al-Qaida di Asia Tenggara.

Dalam penyingkapan beberapa gerakan subversive tahun 1970-an hingga awal 1980-an, yang antara lain melibatkan gerakan Komando Jihad (Komji), Teror Warman, maupun Jamaah Imran, nama Jamaah Islamiyah belum disebut-sebut didalamnya. Baru pada pertengahan tahun 1980-an nama Jamaah Islamiyah muncul dalam beberapa persidangan khusus subvertif komando jihad, teror Warman dan Usroh. Ketika itu Jamaah Islamiyah sering disebut secara bergantian dengan istilah lain yaitu "Kelompok Teror Warman", dan dikaitkan dengan kelompok yang dibentuk oleh kelompok Abdullah Sungkar pada akhir tahun 1970-an yaitu "Jama>'ah Muja> hidin Ansha>rullab". Keberadaan Jamaah Islamiyah itu sendiri dalam kasus tersebut telah dikaitkan dengan kelompok Abdullah Sungkar dan Abdullah Ba'asyir yang memperjuangkan pembentukan Negara Islam Indonesia (NII). Jamaah Islamiyah masih merupakan satu komponen dari jaringan NII. ${ }^{67}$

Pada tahun 1993, beberapa saat setelah putusnya hubungan dengan pimpinan NII Ajengan Masjuki, Abdullah Sungkar mendelegasikan berdirinya Al-Jamaah Al-Islamiyah, atau yang biasa disebut dengan Jamaah Islamiyah (JI) yang terpisah dari struktur NII. Terbentuknya Jamaah Islamiyah menandai keluarnya aktivitas kelompok Abdullah Sungkar dan Ba'asyir dari NII. Sebagaimana telah diuraikan sebelumnya, nama Jamaah Islamiyah itu sendiri telah ada semenjak Sungkar dan Ba'asyir melangsungkan aktivitas Subversifenya di

66 Agus Sunyoto, Walisongo, 80.

${ }^{67}$ M Zaki Mubarak, Genealogi Islam Radikal di Indonesia Gerakan, Pemikiran dan Prospek Demokrasi,(Jakarta: LP3ES, 2007), 324-325. 
Indonesia awal tahun 1980-an. Abdullah Sungkar sendiri telah memiliki reputasi sebagai pimpinan tertinggi (Amir) kelompok bawah tanah Islam, yang sejak tahun 1970-an terus mencoba memperjuangkan pembentukan Negara Islam Indonesia ini dan bahkan Sungkar sendiri telah berhasil membangun jaringanya sendiri dengan kokoh. ${ }^{68}$

Metode perjuangannya banyak dipengaruhi oleh perang Afghanistan. Ini misalnya dapat diamati dari pengakuan Imam Samudra yang dijatuhi hukuman mati dalam kasus bom Bali. "Di sana, saya mendapat banyak perubahan cara berpikir," katanya. Tokoh-tokoh yang mempengaruhi mereka selama di medan perang itu antara lain pimpinan Ikhwanul Muslimin di Yordania, Dr Abdullah Azzam, bekas Mursyid Aam Ikhwan di Mesir Syaikh Mustafa Masyhur dan pemimpin faksi militer Ikhwan di Afganistan Syaikh Prof Dr. Abdur-RabbiRasul Sayyaf.

Untuk memelusuri lebih jauh idiologi dan struktur Jamaah Islamiyah bentukan Abdullah Sungkar setelah bubarnya hubungan dengan NII, maka sebuah buki panduan organisasi yang sempat diterbitkan dan banyak dikenal sebagai PUPJI (Pedoman Umum Perjuangan Jamaah Islamiyah), sedikit banyak memberikan gambaran yang cukup jelas. Arti penting buku PUPJI ini antara lain merupakan pegangan utama bagi para pengurus Jamaah Islamiyah dalam menjalankan dan memahami organisasi. ${ }^{69}$

Temuan terpenting yakni dokumen Pedoman Umum Perjuangan Jamaah Islamiyah (PUPJI) yang dikeluarkan Majelis Qiyadah Markaziyah Al Jamaah Al Islamiyah (Majelis Pimpinan Pusat Jamaah Islamiyah). Dokumen ini berisi prinsip dasar gerakan dalam menegakkan agama, prinsip perjuangan, pedoman operasi, aturan dasar organisasi, kaderisasi dan pembinaan organisasi. ${ }^{70}$

\title{
Peran Ganda Pendidikan dalam wujud Transnasionalisme Islam
}

Pembahasan sebelumnya sudah mendedahkan konsep gerakan Islam Transnasional dengan berbagai bentuknya di Indonesia, yang secara institusional melembaga dan sah secara konstitusional sebagai sebuah organisasi sosial kemasyarakatan dan pendidikan. Seluruh lembaga yang secara eksplisit maupun implisit berafiliasi terhadap gerakan Islam transnasional tersebut menggunakan label Pendidikan Islam sebagai basis gerakan, yang sekaligus berfungsi sebagai mesin ideologinya. Tampak dari paparan data di atas bahwa ada banyak lembaga pendidikan Islam ala transnasional ini yang didirikan sebagai bagian dari gerakan social (social movement), baik itu untuk kepentingan nasional dan kepentingan internasional mereka (baca: ummat Islam secara umum).

Dalam kerangka yang demikian, penulis ingin menggambarkan dua katgorisasi pendidikan Islam yang berkorelasi dengan gerakan sosial-keagamaan. Pertama, pendidikan Islam dijadikan sebagai motor gerakan. Maksudnya, pendidikan Islam dijadikan sebagai sarana untuk mensosialisasikan ideologi dan keyakinan lainnya. Pada umumnya, gerakan semacam ini tergolong Trans-nasional. Pasalnya, di Indonesia, khususnya bagi lembaga pendidikan Islam yang dimotori oleh gerakan nasional, sudah diakomodasi sebagai bagian pendidikan nasional (baca : lembaga pendidikan NU dan Muhammadiyah). Kedua, lembaga pendidikan Islam sebagai counter movement 'lembaga-lembaga baru' yang memiliki motif 'Trans-nasional.

\section{Lembaga Pendidikan Islam sebagai mesin gerakan Trans-nasional}

Lembaga pendidikan sebagai mesin gerakan Trans-nasional berarti memposisikan lembaga pendidikan sebagai bagian strategi untuk menyebarkan ideologi Trans-nasionalnya. Setidaknya ada beberapa lembaga pendidikan Islam yang dibentuk untuk menampung para pengikut gerakan tersebut. Berkaitan dengan ini, penulis akan memberikan gambarannya melalui hasil-hasil

\author{
${ }^{68}$ Ibid., 329. \\ ${ }^{69}$ Ibid., 329. \\ ${ }^{70}$ Ikhsan Abadi, Jama'ah Islamiyah Indonesia, http://www.suara-Islam.com. (diakses 6 Juni 2018).
}


penelitian: salah satunya adalah milik Jajang Jahroni dan Imdadur Rahmat. Objek penelitan Jajang terfokus pada konsep pendidikan LIPIA Jakarta yang merupakan join project dengan Arab Saudi.

Laporan Jajang dari LPPIM UIN Jakarta memasukkan Lembaga pendidikan Indonesia Arab Suadi LIPIA Jakarta sebagai bagian kategori lembaga pendidikan Islam yang disupport oleh gerakan Wahabi di Indonesia. Dia menjelaskan:

"...LIPIA, is a Saudi education project and its network with Indonesian greduates. These returning greduates are currently serving in various positions such as teachers and preachers. In the course of time they have maintained relation with Saudi, from which they obtain financial supports. It focuses on student who studied in Saudi in recent periods precisely in the 1980s, 1990s, and 2000s. Their understanding of sharia have changed over the time depending its contexts" ${ }^{, 71}$.

Lebih lengkapnya dia juga menyebut bahwa eksistensi lembaga tersebut untuk mendirikan identitas baru. Yakni identitas salafisme yang memiliki karakter ritus dan habitus berbeda dengan karakter keislaman di Indonesia. Dia juga menambahkan:

"The ideology of Salafism is further disseminated among the others trough prayer. Prayer is the most important ritual in Islam, and mosque serves the locus where identity, it is better to perform it collectively. By performing collective prayers, student are involed in face to face communication with others. Convertion, expression, shaking hand, kissing, hugging and patting are quite common and ritualized. Performing collective prayer will give deep impact and raise strong in group feelings on each member of the believers. ${ }^{72}$

Dari dua kutipan di atas, terlihat betul bahwa ada kepentingan asing dalam pendirian lembaga pendidikan Islam (political economy of knowledge) di LIPIA ini. Pendanaan Arab Saudi untuk mengembangkan LIPIA terbagi menjadi beberapa bentuk: pertama, dalam bentuk beasiswa bagi siswa atau mahasiswa yang tidak mampu.Kedua, gaji yang berlimpah luah bagi guru atau staff pengajar $^{73}$. Tapi, pastinya, ada syarat yang mesti dipenuhi yakni dengan menjadi bagian dari penyebaran ideologi Wahabi di Indonesia.

Selain laporan Jajang Jahroni yang mengangkat eksistensi Wahabi di Indoesi, Imdadud Rahmat juga menggaris bawahi kesamaan sistem pendidikan yang disediakan oleh partai PKS dengan ikhwanul Muslimin yang berbasis di Mesir. Kesamaan tersebut terletak pada sistem kaderisasi dan gerakan tarbiyah.

“...sistem pengkaderan Tarbiyah PKS merupakan adopsi dan pengembangan dari model pengkaderan Tarbiyah Ikhwanul Muslimin. Pola tarbiyah PKS bisa dikatakan mengadopsi prinsip-prinsip dasar dan sturktur umum Tarbiyah Ikhwanul Muslimin. Hal ini meliputi landasan filosofis, ideologis, dan mabda' (prinsip) keagamaan, tujuan dan target pendidikan, manhaj (metode) dan penetapan, sarana-sarana pendidikan, serta materi pendidikan yang dipakai. Tarbiyah PKS hanya melakukan adaptasi terbatas terkait dengan materi pendidikan serta menghilangkan sarana pendidikan yang tidak sesuai dengan kondisi dan kebutuhan di Indonesia." ${ }^{74}$

Perbedaan antara dua hasil atau kosntruksi penelitian di atas, LIPIA adalah project Arab Saudi dan tidak berimbas pada sebuah gerakan politik. Sedangkan penelitian Imdad, lebih fokus

${ }^{71}$ Jajang Jahroni, “Annual Conference on Islamic Studies (ACIS) ke-12 tanggal 5-8 di Surabaya” dalam The Political Economy of Knowledge: Sharia and Saudi Scholarship in Indonesia, (Jakarta: PPIM UIN,2012), 8.

72 Ibid., 9.

${ }^{73}$ Ibid., 10.

${ }^{74}$ M. Imdadun Rahmat, Ideologi Politik PKS (Yogyakarta: Elkis, 2008), 242. 
pada garis politik PKS dan sebagian saja membahas tentang pendidikan atau Tarbiyah. Satu hal lagi, pendidikan di PKS tidak terbentuk dalam lembaga formal, melainkan pada pembasisan dan pengkaderan berbasis pada kaderisasi organisasi di beberapa kampus di Indonesia.

Penelitian terdahulu mengenai relasi antara dunia pendidikan dengan gerakan Transnasional sempat diulas lengkap oleh Greg Fealy dan Anthony Bubalo. Dalam hasil penelitiannya, dia menyebut LIPIA sebagai project ilmu pengetahuan yang didanai oleh Arab Saudi untuk menyebar luaskan ajaran Wahabisme dan Salafisme. ${ }^{75}$ Selain dua lembaga ini, dia mengutip laporan, ICG tentang salafisme dan organisasi salafi yang menerima dukungan dari luar negeri adalah Yayasan al-Shofwah dan Wahdah Islamiyah ${ }^{76}$

Setidaknya inilah relasi aktif lembaga pendidikan Islam dengan gerakan Islam Transnasional. Sebenarnya masih banyak bentuk-bentuk lembaga pendidikan lainnya yang mendapatkan sponsor dan dukungan finasial, sarana pendidikan, dan lainnya, di Indonesia. Karena, di era yang seperti ini, tak lagi ada batasan bagi masyarakat untuk meminta dan menerima bantuan khususnya dalam konteks dunia pendidikan. Demokrasi menjadikan globalisme mendapatkan ruang yang sangat luas.

\section{Upaya-Upaya Menangkal Gerakan Transnasional}

a. Kontra Narasi Gerakan Sosial Nahdlatul Ulama’

Sudah menjadi mafhum bahwa Nahdlatul Ulama' adalah salah satu lembaga keagamaan yang memiliki posisi tegas terhadap maraknnya fenomena transnasionalisme dan radikalisme di Indonesia bahkan di seluruh dunia. Tampak jelas bahwa secara individual-kultural, para ulama dan kiai NU dalam berbagai ceramah dan agenda dakwah mereka menunjukkan penentangaannya terhadap pemikiran-pemikiran transnasionalisme, dan pada batas tertentu, sudah memperlihatkan ikhtiar konkret untuk ikut terlibat dalam memerangi pemikiran tersebut.

Ideologi Islam trans-nasional sebagai corak dari gerakan radikalisme di Indonesia, akhirakhir ini, menjadi concern dari PBNU dan Muhammadiyah dalam rangka menaggulangi massifitas gerakannya yang mengerikan. Sebagai salah satu Non-Governmental Organizations (NGOs), NU memiliki perhatian yang sangat besar terhadap berkembangnya paham tersebut. Salah satu penelitian mengenai Isu dan radikalisme politik Islam adalah hasil penelitian Miftahul Ilmi, 2008, Persepsi Ulama NU Tentang Sistem Khilafah (Studi Kasus Ulama NU Kota Semarang). Tulisan tersebut mengungkapkan respon NU Kota Semarang dan Ulama NU se Kota Semarang terhadap isu Khilafah dan argumen NU terhadap cita-cita Khilafah Islamiah yang sering dikampanyekan oleh Hizbut Tahrir Indonesia. Dalam tulisan tersebut memperlihatkan secara tegas sikap terhadap NKRI dan Pancasila sebagai konsep yang sudah final di Indonesia sehingga konsep-konsep lain termasuk khilafah yang ditawarkan di Indonesia, pasti akan ditolak. Sikap kebangsaan NU yang kokoh ini diyakini adalah bagian dari ajaran Islam itu sendiri. Nilai kebngsaan yang dimaksud adalah nilai yang berdasarkan kepada nilai-nilai keislaman, khususnya nilai ahlusunnah wal jamaah.

Dalam konteks komintmen dan integritasnya dalam membentengi akidah masyarakat dari ancaman gerakan Islam transnasional, menurut Hasbi Anwar, NU sudah sejak dahulu kala melakukannya. Sikap NU terhadap NKRI dan kebangsaan, bisa dilihat komitmen NU terhadap eksistensi negara Indonesia. Sikap NU ini terlihat dari berbagai peristiwa politik yang terjadi sebelum Indonesia dideklarasikan hingga saat ini. Indonesia telah diakui oleh NU sebagai darul Islam, negara Islam dan setiap pemimpinnya diakui sebagai pemimpin yang sah dalam pandangan fiqih Nahdlatul Ulama. ${ }^{77}$

\footnotetext{
75 Greg Fealy dan Bubablo, Jejak. Kafilah, 94

76 Ibid. 99

77 Hasbi Aswar, Organisasi Nabdatul Ulama Memerangi Radikalisme Politik Islam di Indonesia, (Program Studi
} Hubungan Internasional Fakultas Psikologi dan Ilmu Sosial Budaya Universitas Islam Indonesia Yogyakarta, 2015), 30. 
Pasca orde baru, gerakan-gerakan yang ingin menegakkan Negara Islam ikut meramaikan pergerakan Islam di Indonesia akibat kran-kran yang sebelumnya tertutup rapat sudah mulai terbuka. Opini gerakan-gerakan tersebut cenderung mendominasi dan mengalahkan gerakan Islam seperti NU dan Muhammadiyah. ${ }^{78}$ Akhmad Sahal, Wakil Ketua Pengurus Cabang Istimewa NU (PCINU) Amerika-Kanada, mengungkapkan kekhawatiran yang sama dialami Rubaidi, Menurut Sahal, Suara NU dan Muhammadiah tak lagi tampak sebagai pemain utama dan malah cenderung terdesak oleh berbagai organisasi lain dalam percaturan wacana keislaman menurut Sahal. Bahkan gaung gerakan seperti HTI dan FPI cenderung lebih keras dibanding kedua organisasi besar yang ada di Indonesia. NU jelas tidak tinggal diam, para petinggi dan ulama NU secara tegas di berbagai kegiatan menyatakan sikap penolakan NU terhadap gerakangerakan tersebut bahkan, dari berbagai pertemuan pimpinan dan ulama NU, isu yang menjadi pembicaraan penting adalah penolakan mereka terhadap perjuangan negara Islam atau khilafah serta mengajak untuk mempertahankan dan membela NKRI. ${ }^{79}$

b. Kontra Narasi Perlembagaan Ideologi Pancasila dan Moderatisme Islam

Poros nasionalisme ulama dengan menerima Pancasila sebagai dasar negara Indonesia, secara historis, memang merupakan sikap moderat dan paling pilihan paling rasional dan relevan untuk menjaga persatuan Indonesia, sekaligus menjaga keberlangsungan beragama ${ }^{80}$. NU dan Muhammadiyah sebagai organisasi yang terdepan dalam pembelaan nasionalisme Indonesia tidak tertarik untuk melakukan formalisasi hukum Islam dalam kehidupan kebangsaan dan kenegaraan sebagaimana pemberlakuan hukum Islam dalam ruang publik, tata negara, dan administrasi negara, termasuk hukum privat keluarga seperti perkawinan, waris, dan perbankan. NU sendiri sebelum masa kemerdekaan melalui muktamar ke-11 pada 1936 di Banjarmasin mengukuhkan Indonesia sudah sebagai negara Islam karenamasyarakatnya mayoritas beragama Islam dan tidak ada larangan menjalankannya kendati dipimpin oleh Kerajaan Protestan Belanda. ${ }^{81}$

\section{Restrukturisasi Pemahaman Aswaja an Nahdliyah di Kab. Lumajang}

Kata restrukturisasi yang penulis gunakan dalam konteks riset ini, tidak sekedar persoalan pembentukan proses desiminasi pengembangan nalar aswaja khas nahdlatul ulama' dari sisi diskursus, melainkan juga bagaimana proses desiminasinya lebih konstruktivis dibandingkan yang ada sebelumnya. Kendati, harus penulis juga akui, kontestasi ideology yang ada di Kab. Lumajang tidak sekuat dengan yang ada di daerah-daerah lainnya, semisal fenomena yang kerap terjadi di Kab/Kota di Jawa Barat ataupun di Aceh; dimana ideologisasi keagamaan juga bermain secara politik. Artinya, kendati LP Maarif Kab. Lumajang melakukan restrukturisasi desiminatif terhadap komponen-komponen keaswajaan yang dijalankan, tidak akan banyak masyarakat yang menganggap hal tersebut sebagai abuse of power dari kelompok mayoritas terhadap minoritas. Jadi, restrukturisasi ini dijalankan untuk membentuk kerangka strategis "menghadang" ideology radikal mengantarkan pengaruhnya secara kelembagaan yang ada di Kab. Lumajang. Atau, sebagai langkah antisipatif semata.

Sebagaimana yang sudah dinyatakan sebelumnya, maka rekognisi terkait paham keaswajaan menjadi sangat penting. Dalam paparan data dinyatakan bahwa: Dari asumsi ini, maka pertama mengasumsikan apa yang dilakukan oleh LP Ma'arif dan seluruh lembaga pendidikan di

${ }^{78}$ Jatuhnya Soeharto, menurut Noorhaidi Hasan, terbukti menjadi terobosan demokratik yang sangat menentukan. Di bawah kepresidenan transisional Habibie dan penggantinya, Abdurrahman Wahid, proses liberalisasi dan demokratisasi berjangka panjang, yang terjadi bersamaan dengan melemahnya kekuasaan negara, telah mengubah seluruh lanskap politik Indonesia. Selengkapnya, lihat: Noorhaidi Hasan, Laskar Jihad, Islam, Militansi, dan Pencarian Identitas di Indonesia Pasca Orde Baru, (Jakarta: LP3ES \& KITLV-Jakarta, 2008), 2.

${ }^{79}$ Hasbi Aswar, Organisasi Nabdatul Ulama, 30

80 Muh. Khamdan, "Pengembangan Nasionalisme Keagamaan sebagai Strategi Penanganan Potensi Radikalisme Islam Transnasional” dalam ADDIN, Vol. 10, No. 1, Februari 2016, 221.

81 Jimmy Oentoro, Indonesia Satu, Indonesia Beda, Indonesia Bisa (Jakarta: Gramedia Pustaka Utama, 2010), 167. Tarbiyatuna: Jurnal Pendidikan Islam;Volume 12, Nomor 2, Agustus 2019| 195 p-ISSN: 2085-6539; e-ISSN: 2242-4579 
lokasi penelitian berkesesuaian dengan kerangka teori yang sudah ada merupakan hal yang sah. Artinya, dari data yang penulis dapatkan, PCNU Lumajang melalui LP Ma'arif sudah melakukan reaktualisasi nilai-nilai keaswajaan sesuai dengan apa yang dirumuskan oleh Pengurus Besar Nahdlatul Ulama'. Sebagaimana ungkapan dari semua nara sumber bahwa aswaja yang ditanamkan, dikaji, dan diajarkan kepada seluruh masyarakat disandarkan pada pemahaman yang kontekstual. Tidak lagi tekstual seperti yang ada di era klasik dalam Islam. Kedua, dalam konteks pendekatan dan strategi yang dijalankan LP. Ma'arif NU dan lembaga di bawahnya pun sudah berkesesuaian dengan apa yang ada dalam teori. Mereka melakukan internalisasi melalui proses sosialisasi langsung kepada masyarakat, lembaga pendidikan melalui bahan ajar, pengenalan di masa orientasi, dan kegiatan-kegiatan lain yang melibatkan secara langsung para generasi muda untuk ambil bagian menghadirkan aswaja ala NU tersebut.

Ketiga, LP Ma.arif NU Lumajang melakukan re-inforcement dan pengkaderan secara massif agar pemahaman aswaja an nahdliyah tersebut mendarah daging di kalangan anggota NU. Dengan demikian, secara normative, penulis ingin mengatakan bahwa kerangka berfikir sebagaimana visi dan misi Ketua LP. Ma'arif NU Lumajang - melakukan perbaikan pola organisasi dan penguatan SDM, hingga layanan masyarakat dapat termanifestasi secara baik dalam proses sosialisasi Aswaja An-Nahdliyah dikalangan pemuda NU di Kabupaten Lumajang. Walaupun, juga terdapat masalah-masalah baru yang harus diselesaikan misalnya terkait pola koordinasi antara satu bagan dengan bagan yang lain, atau antara instansi pemerintah yang satu dengan instansi pemerintah yang lain.

Komponen ini, apabila dibaca secara nalar konstruktivis, maka modal utama internalisasi nilai-nilai keaswajaan yang ada di Kab. Lumajang hadir pada pemahaman dan pemaknaan terhadap aswaja al Nahdliyah. Aswaja yang dirumuskan dengan modal menghargai dan menampakkan apa yang sudah diyakini oleh masyarakat Nabdliyin sebelumnya. Jadi, untuk membangun internalisasi nilai, maka membutuhkan beberapa langkah kongret sebagaimana berikut:

1. Reaktualisasi pemahaman dan pemaknaan keaswajaan yang diyakini masyarakat

2. Memantapkan nilai-nilai identic sebagai sebuah kebenaran yang utuh. Kebenaran yang bukan sekedar terbangun dari sikap apologetisme pemikiran seorang tokoh semata, melainkan sudah secara kolektif diyakini oleh para kyai.

3. Kyai - dalam nalar eidetic - ada rumus fenomenologisme yang tidak bisa digantikan menggunakan pandangan globalisme. Maka dari itu, peran dan kmomponen penceramah harus tetap bisa dijalankan sebagai bingkai kulktural untuk melawan apa yang dijalankan kelompok-kelompok radikal.

Tentu, karena hal ini berhubungan dengan lembaga pendidikan LP Maarif memiliki kewajiban untuk mendesiminasikan pemahaman-pemahaman rasional-identik tersebut menjadi sebuah wacana yang sistematis. Dalam ranah ini, maka struturasi bisa dijalankan menggunakan pendidikan:

1. Pembudayaan dan habituasi sistemik pada iklim lembaga pendidikan berdasarkan pahampaham Aswaja al Nahdliyah

2. Pengutamaan pengetahuan keislamaan berbasis nilai-nilai aswaja al Nahdliyah

3. Adanya kurikulum khusus atau terintegrasi dalam setiap pengajaran yang ada di Lingkungan pendidikan.

4. Menyediakan guru dan pengajar yang mampu memahami aswaja sebagai sebuah "nalar perlawanan" bagi kelompok-kelompok transnasional yang ada di Indonesia. Artinya, para guru sudah sangat memahami dimensi sosiologis yang hadir sebelum mereka memberikan pemahaman kepada para siswa.

Sekali lagi, konstruktivisme di dalam bingkai riset ini, seakan menjadi monolog, tidak bisa dilepaskan dari kondisi sosilogis dan politik masyarakat Lumajang yang memang memiliki kekuatan ideologis terhadap Nahdlatul Ulama' itu sendiri. Jadi, membangun konstruktivisme melalui lembaga pendidikan berdasarkan pada nilai-nilai keaswajaan bukanlah hal yang sangat sulit 
dijalankan, dan mustahil untuk dilakukan kanalisasi pemahaman masyarakat dan generasi muda dalam memahami keislaman yang khas Indonesia.

\section{Re-Kulturisasi Aswaja al Nahdliyah dan Objektivasi Kelompok Transnasional di Lumajang}

Dari sudut pandang ini, re-kulturasi keislaman khas Nahdlatul Ulama' harus lebih ditampakkan sebagai distingsi dari cara berfikir kelompok-kelompok global tersebut. Beberapa perbedaan identitas kebudayaan tersebut ialah:

Entitas Kebudayaan NU vis a vis Kelompok Transnasional

\begin{tabular}{|l|l|}
\hline Konstuksi Kebudayaan Pendidikan NU & Kontruk Pendidikan Transnasional \\
\hline Menghargai nilai kebudayaan nusantara & $\begin{array}{l}\text { Mendahulukan nilai-nilai normatif Islam/ } \\
\text { menghapus tradisi yang dianggap tidak sesuai } \\
\text { dengan pandangan Islam-Normatif }\end{array}$ \\
\hline $\begin{array}{l}\text { Mendahulukan pendekatan persuasif/ } \\
\text { toleran terhadap perbedaan yang ada di } \\
\text { masyarakat }\end{array}$ & $\begin{array}{l}\text { Memaksakan kehendak/cenderung menyalahkan } \\
\text { paham orang lain }\end{array}$ \\
\hline $\begin{array}{l}\text { Mengedepankan tauladan /kesadaran } \\
\text { masyarakat }\end{array}$ & Indoktrinasi Ajaran Keislaman \\
\hline Tanpa Pamrih dalam berdakwah & Memiliki tujuan tertentu \\
\hline Menghormati para pendahulu & Mengandalkan ketokohan pemimpin gerakan \\
\hline
\end{tabular}

Jikalau dikembalikan kepada ruang riset ini, maka komponen-komponen tersebut tidak bisa dinafikan, kalau sekolah atau madrasah yang berada di bawah naungan LP Maarif NU Kab. Lumajang berada pada iklim dan kebudayaan NU itu sendiri. Dalam upaya untuk membangun dan mengkonstruk kebudayaan yang nafas utamanya adalah toleransi, keramahan, dan terbuka terhadap perkembangan zaman sangatlah mudah untuk dilakukan. Distingsi non-indoktriner juga bisa ditampilkan, kendati hal ini harus didekati menggunakan kerangka berfikir yang lebih persuasive juga. Artinya, proses pendidikan yang dijalankan harus juga menunjukkan kesadaran pembenar bahwa apa yang dijalankan tersebut merupakan bagian dari upaya untuk menghentikan arus gerak paham transnanasional yang ada di Indonesia.

Untuk membangun kanal ekternalisasi tersebut, maka Lembaga Pendidikan di bawah naungan LP Maarif NU Kab. Lumajang juga harus diperkenalkan bagaimana strategi yang dipakai oleh kelompok radikal tersebut; berikut ini adalah table yang akan menjelaskan bagaimana model pengembangan pengenalan antisipatif yang bisa dijalankan dalam wujud kontruksi kebudayaan dan institusionalisme di LP Maarif Kab. Lumajang

\section{Utilitialianisme Paham Keaswajaan dalam dunia Pendidikan di Kab. Lumajang}

Berdasarkan pada kerangka-kerangka berfikir di atas, maka sudah dua komponen teoritik yang bisa digapai untuk menangkal transnasionalisme Islam di dalam dunia pendidikan. Pada komponen terakhir bagaimana kontruksi Peter L Berger ini bisa menjadi carapandang baru menangkal radikalisme ialah melalui proses eksternalisasi bisa dijalankan. Dalam pembacaan penulis pola sosialisasi yang konfrehensif yang dilakukan oleh LP Maarif NU Kab. Lumajang ini bisa disebut sebagai holistic-approaching of constructivism.

Berdasarkan analisis, maka dapat disimpulkan bahwa, untuk menjadikan pola penyampaian aswaja sangat efektif bagi kalangan pemuda, dibutuhkan upaya-upaya yang menyeluruh, para penyampai (preacher) tidak sekedar memahami materi yang dibutuhkan, melainkan juga strategi penyampaian yang efektif dan tidak menjemukan. Mereka juga diharapkan bisa membungkus teori atau istilah yang ada di dalam konsepsi aswaja an nabdliyah menjadi lebih mudah dipahami sesuai dengan cara berfikir objek yang dihadapi. Setelah mereka mendapatkan pemahaman, maka diperlukan pembuktian yang dilaksanakan secara kolektif. Kolektifitas tindakan ini sangat penting, agar mereka (baca; yang memahami aswaja an nahdliyah ini) tidak 
teralienasi dari komunitas yang ada. Terakhir, dibutuhkan pula proses kesinambungan agar keyakinan tersebut tidak mudah punah. Salah satu cara yang efektif adalah membentuk sebagai habitus objektif dan kebenaran absolute. Dalam bahasa yang lebih sederhana, mereka secara tidak sadar, bahwa apa yang dilakukannya sudah menjadi dogmatisme yang tidak akan mudah diubah oleh kepentingan sesaat.

Kerangka lain yang tidak bisa diakses adalah melakukan proses generalisasi pendidikan di luar lembaga pendidikan Islam (baca; pesantren). Di luar pesantren tidak memiliki role-model (Kyai) laiknya yang ada di pesantren. Oleh karena itu, diperlukan proses-proses pembaharuan untuk bisa menghadirkan pendidikan toleran berbasis pada nilai-nilai kepesantrenan ini sebagai basis utama sistem pendidikan nasional. Salah satu caranya adalah membingkai ulang desain pendidikan toleransi di luar, kemudian membawanya ke pengalaman-pengamalan yang basis nilainya ada di lembaga pesantren. Hal tersebut, dalam wujud implementasi, tentunya tidak sulit. Pasalnya, branding of full-day school dan building of Islamic Culture sudah menjadi primadona di kalangan masyarakat Indonesia, utamanya mereka yang berada di wilayah perkotaan.

Betapapun rancang bangun identitas Islam di Indonesia tidak akan pernah lepas dari nilainilai toleransi dan kesadaran takdiri bahwa nusantara dibangun dari keragaman. Nusantara dibentuk dari perbedaan-perbedaan yang berkembang tanpa proses diminta. Oleh karena itulah, memotret Islam-Indonesia vis a vis dengan gerakan penyeragaman yang dilakukan oleh gerakan transnasional sebenarnya bukan perkara yang sulit. Indonesia memiliki identitas keislaman yang dipresentasikan dan dipreferensikan melalui dua organisasi yang lahir memberikan kontribusi terhadap berdirinya bangsa Indonesia; yakni Nahdlatul Ulama' dan Muhammadiyah keduanya pun memiliki cara dan strategi tersendiri untuk mengkonstruk masyarakat Indoensia. Muhammadiyah bisa jadi melalui cara-cara dan jalan rasionalisme ilmiah, sedangkan NU melalui karakteristik yang dibangun di pondok pesantren.

Oleh sebab menjadikan pendidikan pesantren merupakan miniatur Indonesia yang beragam, memindahkan nilai-nilai keislaman pesantren yang toleran dan plural, juga merupakan sebuah keniscayaan. Hal yang dibutuhkan adalah melakukan konstruksi sosial, membingkai nilai, dan memantapkan regulasi serta komitmen bersama, untuk menciptakan lembaga pendidikan Islam yang toleran dan plural. Lebih-lebih, lembaga pendidikan di luar pondok pesantren memiliki kekuatan (internal/eksternal); apakah itu Sumber Daya Manusia ataupun Sumber Daya Alam, yang dapat mendukung dan menguatkan apapun yang sudah dicanangkan oleh lembaga pendidikan formal. In the end, apapun gagasan yang penulis tuangkan di atas, merupakan proses postulasi Islam-Indonesia yang sangat toleran dan berbeda dengan gerakan transnasional Islam, dalam mengahadapi masalah masyarakat, serta Islam-Indonesia memiliki keunikan pendekatan untuk mereproduksi generasi muda yang toleran dan plural, melalui sekolah Islam ataupun pendidikan pesantren.

\section{Kesimpulan}

Sekolah atau madrasah yang berada di bawah naungan LP Maarif NU Kab. Lumajang ternyata memiliki iklim dan kebudayaan NU itu sendiri. Dalam upaya untuk membangun dan mengkonstruk kebudayaan yang nafas utamanya adalah toleransi, keramahan, dan terbuka terhadap perkembangan zaman sangatlah mudah untuk dilakukan. Distingsi non-indoktriner juga bisa ditampilkan, kendati hal ini harus didekati menggunakan kerangka berfikir yang lebih persuasive juga. Bahkan untuk membangun kanal ekternalisasi tersebut, maka Lembaga Pendidikan di bawah naungan LP Maarif NU Kab. Lumajang juga harus diperkenalkan bagaimana strategi yang dipakai oleh kelompok radikal tersebut.

Berdasarkan analisa-teoritik, maka kesimpulannya, untuk menjadikan pola penyampaian aswaja sangat efektif bagi kalangan pemuda, dibutuhkan upaya-upaya yang menyeluruh, para penyampai (preacher) tidak sekedar memahami materi yang dibutuhkan, melainkan juga strategi penyampaian yang efektif dan tidak menjemukan. Mereka juga diharapkan bisa membungkus teori atau istilah yang ada di dalam konsepsi aswaja an nabdliyah menjadi lebih mudah dipahami 
sesuai dengan cara berfikir objek yang dihadapi. Setelah mereka mendapatkan pemahaman, maka diperlukan pembuktian yang dilaksanakan secara kolektif. Kolektifitas tindakan ini sangat penting, agar mereka (baca; yang memahami aswaja an nahdliyah ini) tidak teralienasi dari komunitas yang ada. Terakhir, dibutuhkan pula proses kesinambungan agar keyakinan tersebut tidak mudah punah. Salah satu cara yang efektif adalah membentuk sebagai habitus objektif dan kebenaran absolute. Dalam bahasa yang lebih sederhana, mereka secara tidak sadar, bahwa apa yang dilakukannya sudah menjadi dogmatisme yang tidak akan mudah diubah oleh kepentingan sesaat.

\section{Referensi}

Abdullah, Amin. 2011. Reaktulisasi Islam Yang Berkemajuan; Agenda Strategis Mubammadiyah di Tengah Gerakan Keagamaan Kontemporer. Makalah Pengajian Ramadhan di Universitas Muhammadiyah Yogyakarta

Asy'ari, Hasyim. 2006. Al-Qanun Al-Asasi; Risalah Ablus Sunnab Wal Jama'ah, terjemah oleh Zainul Hakim, Jember: Darus Sholah

Ball, Stephen. 2004. The Routledge Falmer Reader of Sociology of Education. New York; Routledge Falmer.

Bizawie, Zainul Milal. 2016. Mastepiece Islam Nusantara; Jejaring dan Sanad Ulama'-Santri. Jakarta: Pustaka Kompas.

Departemen Agama RI. 2012. Moderasi Islam, Tafsir al-Qur'an Tematik. Jakarta: Lajnah Pentashihan Mushaf al - Qur'an.

Fuad, A. Jauhar, Asyari, Imam Taulabi. 2015. Waspada Penetrasi Neo-Salafi Wahabi di Madrasah NU. Kediri: Al Maktab.

Gaus AF, Akhmad, "Pemetaan Problem Radikalisme di SMU Negeri di 4 Daerab", dalam Jurnal Ma'arif Institute, Vol. 8, 1, 2013.

Giroux, Henry A. ed, 2001. Education and Cultural Studies. New York; Routledge

Merlyna Lim. 2011. "Radical Islamism in Indonesia and Its Middle Eastern Connection," dalam Meria Journal, Volume 15, Issue 2 June Tahun 2011

Mufid, Ahmad Syafi'i. 2011. Perkembangan Faham Keagamaan Transnasional di Indonesia. Jakarta: Badan Litbang dan Diklat Kementriaan Agama RI

Mujani, Saeful. Umat Islam Indonesia Dukung Radikalisme. Jakarta: Harian Tempo: 12 November 2004.

Naim, Ngainun. 2015. Pengembangan Pendidikan Aswaja sebagai Strategi Deradikalisasi, Jurnal Penelitian Keagamaan. Tulungagung: IAIN Tulunggung

O’Donnell, Mike. 2004. "The Social Construction Of Youthful Musculinities" dalam Stephen Ball The Routledge Falmer Reader of Sociology of Education. New York; Routledge Falmer

PBNU. 2016. Hasil-basil muktamar ke-33 Nabdlatul Ulama. Jakarta: Lembaga Ta'lif wan Nasyr PBNU

PP Lakpesdam NU. 2017. Nasional-isme dan Islam NU-Santara. Jakarta: PT. Kompas Media Nusantara

Prasetiawati, Eka. 2017. Menamankan Islam moderat upaya menanggulangi radikalisme di Indonesia, Jurnal Iqra Metro lampung: Institut Agama Islam Ma'arif NU.

PWNU Jawa Timur. 2007. Ablusunnah wal Jama'ah An-Nabdliyah. Surabaya, Khalista.

Qodir, Zuly. 2014. Radikalisme Agama di Indonesia. Yogyakarta: Pustaka Pelajar.

Siraj, Said Aqil. 2011. dalam Muhammad Idrus Ramli, Pengantar Sejarah Ablussunah Wal Jama'ah. Jakarta: Khalista

Sunanto, Musyrifah. 2015. Sejarah Peradaban Islam Indonesia. Jakrta: PT. Rajagrafindo persada

The Wahid Institute, dan Maarif Institute. 2009. Ilusi Negara Islam: Ekspansi Gerakan Islam Transnasional di Indonesia. Jakarta: PT. Desantara Utama Media

Tilaar, HAR 2003. Pendidikan dan Kekuasaan. Bandung; Rinneka Cipta.

Turmudzi, Endang. 2005. Islam dan Radikalisme di Indonesia. Jakarta: LIPI Press 
Wahyudin, Didin. 2016. Pendidikan Aswaja sebagai upaya menanggal Radikalisme, Jurnal Dinamika Penelitian, Tulung Agung: IAIN Tulung Agung.

Zada, Khamami. 2002. Islam Radikal: pergulatan ormas-ormas Islam garis keras di Indonesia. Jakarta: Teraju.

Zadja, Joseph. 2009. Globalisation, Policy, and Comparative Research. Australia; Springer Science.

Internet

http://m.jatimtimes.com/baca/156016/20170727/163334/ada-4-pns-di-lumajang-diketahuisebagai-anggota-hti/

http://nasional.kompas.com/read/2017/07/19/10180761/hti-resmi-dibubarkan-pemerintah

http://news.liputan6.com/read/3146828/survei-23-persen-lebih-mahasiswa-pelajar-terdoktrinradikalisme

http://www.Allkhwan.net,

http://www.alsofwah.or.id

http://www.Assunnah.or.id

http://www.eramuslim.com

http://www.nu.or.id

http://www.nu.or.id/post/read/27947/buletin-radikal-beredar-di-lumajang

http://www.syariahonline.com

https://nasional.tempo.co/read/229078/selebaran-gelap-tentang-pks-berpaham-wahabi-beredardi-lumajang

https://www.cnnindonesia.com/nasional/20170512135522-12-214314/kepala-bin-hti-inginganti-pancasila-jadi-khilafah

https://www.jawapos.com/read/2017/06/12/137132/waspadalah-isis-sudah-masuk-di-16daerah-jawa-timur

https://www.merdeka.com/peristiwa/wanita-ini-beberkan-perkenalan-dengan-wni-simpatisanisis-di-turki.html 